\title{
Larval development of the Chinese mitten crab Eriocheir sinensis H. Milne-Edwards (Decapoda: Grapsidae) reared in the laboratory
}

\author{
M. Montú ${ }^{1}$, K. Anger ${ }^{2} \&$ C. de Bakker ${ }^{3}$ \\ ${ }^{1}$ Fundação Universidade do Rio Grande, Base Oceanográfica Atlântica; \\ 96.200 Rio Grande, RS, Brazil \\ ${ }^{2}$ Biologische Anstalt Helgoland, Meeresstation; 27483 Helgoland, Germany \\ ${ }^{3}$ Centro de Biologia Marinha, Universidade Federal do Paraná; \\ 80.000 Curitiba, PR, Brazil
}

\begin{abstract}
Larvae of the Chinese mitten crab Eriocheir sinensis were reared in the laboratory from the time of hatching and through metamorphosis. Development normally consists of a Prezoea, 5 Zoea stages, and a Megalopa. Occasionally, an additional (stage VI) Zoea and, in one case, an additional Megalopa (transitional to the first crab stage) were observed. Detailed morphological descriptions of all larval and the first two juvenile instars are given, and larval morphology is compared with that of two closely related species, Eriocheir japonicus and Eriocheir rectus, descriptions of which have recently become available. The zoeal stages of these species can be distinguished by their different number of aesthetascs and setae on the antennules, and different setation of maxillipeds 1 and 2. The Megalopa shows differences in the shape of the rostrum and again in the morphology of the antennule. These and other morphological differences (mainly in setation and spinulation of the zoeal carapace) between $E$. sinensis and $E$. japonicus larvae suggest that they may be very closely related but separate species; this contradicts a recent study of adult morphometrics and molecular genetics (Li et al., 1993), suggesting that they are only varieties of a single species.
\end{abstract}

\section{INTRODUCTION}

The mitten crab Eriocheir sinensis was introduced early this century from China to German rivers, from where it spread over great parts of Europe (Panning, 1933). While the juvenile and adult stages have been investigated in much detail (review of old literature: Panning, 1938; for recent references see Bianchini \& Gilles, 1990; Lee \& Yamazaki, 1990), very little is known about the larvae of $E$. sinensis. Rough and incomplete descriptions of their morphology were given by Schnakenbeck (1933) and Panning (1939). The latter author suggested the existence of 4 zoeal stages and a Megalopa (Panning, 1936a). Panning (1936b) and Hinrichs \& Grell (1937) concluded from field observations that the larvae perform ontogenetic horizontal migrations during their development in estuarine and coastal regions.

First, only partially successful rearing experiments were carried out by Buhk (1938). Anger (1991) reared the larvae of $E$. sinensis under controlled conditions from the time of hatching and through metamorphosis, studying effects of temperature and salinity on 
survival and development. In the present paper, the morphology of all larval and the first two juvenile stages is described and compared with that of closely related species, Eriocheir japonicus (Kim \& Hwang, 1990) and Eriocheir rectus (Shy \& Yu, 1992); however, according to a recent taxonomical revision of adult material (Chan et al., 1995), the larvae described in the latter paper did not belong to $E$. rectus, but to a new species, Eriocheir formosa. The comparison of larval morphology in E. sinensis and E. japonicus became particularly interesting since Li et al. (1993) concluded from morphometric and biochemical evidence that these two species, which co-exist in some Chinese rivers, should actually be only varieties of a single species.

\section{MATERIAL AND METHODS}

Ovigerous mitten crabs were dredged in early 1989 from the outer Elbe estuary (North Sea) and transported to the Helgoland marine biological station, where they were maintained at constant $12{ }^{\circ} \mathrm{C}$ and $20 \% \mathrm{~S}$ until larvae hatched (in May). Larvae were reared both individually in vials $\left(30 \mathrm{~cm}^{3}\right)$ and communally in bowls $\left(400 \mathrm{~cm}^{3}\right)$ at 25 different combinations of temperature $\left(6,9,12,15\right.$, and $\left.18^{\circ} \mathrm{C}\right)$ and salinity $(10,15,20,25$, and $32 \%$ ). Water and food (freshly hatched San Francisco Bay Brand ${ }^{\mathrm{TM}}$ Artemia spec. nauplii) were either changed daily (at $\geq 12^{\circ} \mathrm{C}$ ) or every second day (at $\leq 9^{\circ} \mathrm{C}$ ). Further details of rearing conditions are given in a previous paper by Anger (1991), where effects of temperature and salinity on rates of larval development and survival are described. The exuviae and dead larvae from these experiments were used in the present study, in addition to material obtained from cultivation experiments that were carried out exclusively for morphological studies.

Specimens of larvae and exuviae were fixed in $4 \%$ seawater-formaldehyde. Later, at least 20 individuals of each larval stage (where available) were measured and dissected under Wild stereo microscopes. Material was also available for the study of exceptionally occurring additional stages (Zoea VI, Megalopa II). Drawings were made with the aid of a camera lucida attached to a Leitz compound microscope. The drawings of whole larvae and single appendages thereof are not grouped by stage but by character (e.g. total lateral view of larva, antenna, telson, etc.), so that each plate shows the development of one character.

The following abbreviations are used: $\mathrm{CL}=$ carapace length from orbit to posterior carapace border; $\mathrm{CW}=$ carapace width measured at the widest part of carapace; DS-RS $=$ distance from tip of dorsal spine (DS) to tip of rostral spine (RS); LS = lateral spine; $\mathrm{P}_{1}-\mathrm{P}_{5}=$ pereiopods $1-5 ; \mathrm{Pl}_{1}-\mathrm{Pl}_{5}=$ pleopods $1-5 ; \mathrm{TL}=$ total length from tip of the rostrum to the posterior border of the telson (only for Megalopa).

\section{RESULTS}

Larval development of Eriocheir sinensis consists normally of a brief, non-feeding Prezoea, five Zoea-stages, and a Megalopa. At $15^{\circ} \mathrm{C}$ in combination with low salinity (15\% S), survival rate was poor (Anger, 1991), and five individuals passed a sixth zoeal stage before reaching the Megalopa. In one case (at $5 \% \mathrm{~S}$, after stepwise reduction of salinity) an additional Megalopa was observed; however, this individual died before metamorphosis. Since such unfavourable conditions also occur in the field, namely in 
estuarine environments, additional larval stages may exist also there and are thus described here as well. No other effects of rearing conditions on larval morphology were observed.

\section{Prezoea}

Size: TL 1.23-1.48 mm; CL $0.48-0.52 \mathrm{~mm}$.

Carapace (Fig. 1A): Cephalothorax globose, with rostrum, DS and LS developing; DS pointed toward rostrum.

Antennule: Three aesthetascs emerging, 2 spines.

Antenna: Protopod and exopod emerging.

Mandible, Maxillula, Maxilla: Nonfunctional, all embedded in mass of cells.

Maxillipeds: Biramous, covered with cuticular sheaths. Maxillipeds 1 and 2 with 5 segments.

Abdomen: Five somites. Somites 2, 3 and 4 with a knob on each medial lateral surface. Telson (Fig. 14A): Rectangular, furca and setae emerging from cuticular sheath.

\section{Zoea I}

Size: CL $0.64-0.67 \mathrm{~mm}$; DS-RS $1.25-1.27 \mathrm{~mm}$.

Carapace (Fig. 1B): Cephalothorax punctuated, DS well developed, covered with small spines, longer than RS and lateral spine; RS covered with small spines; LS with small spines on surface; posterolateral region with 6-9 spines on each side. Eyes unstalked.

Antennule (Fig. 3A): Conical and slender with 3 aesthetascs and 2 setae of different size.

Antenna (Fig. 4A): Long protopod with short spines along margins; exopod small with terminal and lateral spines.

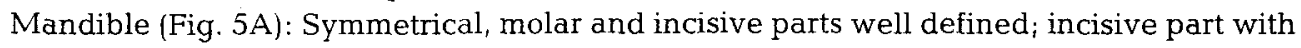
2 ventral teeth.

Maxillula (Fig 6A): Endopod 2-segmented; proximal article with 1 long seta; distal article with 4 terminal and 1 subterminal plumose setae; basal endite with 4 spines and 1 seta; coxal endite with 5 setose spines.

Maxilla (Fig. 8A): Endopod bilobed with 2, 2 terminal setae; basal endite bilobed with 4, $4 \mathrm{sp} / \mathrm{setae}$; coxal endite bilobed with 2, 3 setae; scaphognathite with 3 plumose, 2 smooth setae plus 1 plumose projection.

Maxilliped 1 (Fig. 10A): Basis with 6 ventral setae; exopod with 4 natatory setae; endopod 5-segmented with 1, 1,2, 2, 5 setae.

Maxilliped 2 (Fig. 12A): Basis with 3 sparsely plumose setae; exopod with 4 natatory setae; endopod 3-segmented with 0, 1,5 sparsely plumose setae.

Abdomen (Fig. 14B): Five somites; somites 2, 3 and 4 with small hook on each lateral surface; somite 5 with posterolateral spines overlapping the telson. Somites $3-5$ with 2 minute dorsal setae.

Telson (Fig. 14B): 3 pairs of setae on posterior margins, with spines and minute setae; one dorsal marginal series of spinules and one on internal margin of furca. 


\section{Zoea II}

Size: CL $0.68-0.71 \mathrm{~mm}$; DS-RS $1.56-1.60 \mathrm{~mm}$.

Carapace (Fig. 1C): As in Zoea I, with series of 5 plumose setae on the upper posterolateral region, marginal part with alternate series of spines and minute setae; small spines on DS and LS reduced as compared to Zoea I. Eyes stalked.

Antennule (Fig. 3B): As in Zoea I, but with 3 aesthetascs, 1 short, 1 minute setae.

Antenna (Fig. 4B): As in Zoea I, but with exopod more developed.

Mandible (Fig. 5B): As in Zoea I, molar part well developed with little teeth, incisive part more developed.

Maxillula (Fig. 6B): Endopod 2-segmented, with 1 smooth and 5 sparsely plumose setae; basal endite with 7 serrate spines; coxal endite with 5 serrate spines; protopod with 1 plumose seta.

Maxilla (Fig. 8B): Endopod bilobed with 2, 2 sparsely plumose setae; basal endite bilobed with 3 stout sparsely plumose, 1 fine and 5 stout plumose setae; coxal endite with 3 and 4-5 stout sparsely plumose setae; scaphognathite with 8 plumose setae.

Maxilliped 1 (Fig. 10B): Basis with sparsely plumose setae arranged in groups of 2 and 3; exopod with 6 plumose setae; endopod 5 -segmented with $2,1,1,2,5$ setae.

Maxilliped 2 (Fig. 12B): Basis with 4 sparsely plumose setae; exopod with 5 terminal plumose setae; endopod with $0,1,5$ setae.

Maxilliped 3: Small bud.

Abdomen (Fig. 14B): As in Zoea I, but with short posterolateral process on somites 3, 4, 5.

Telson (Fig. 14B): As in Zoea I.

\section{Zoea III}

Size: CL 0.76-0.80 mm; DS-RS 1.98-2.05 mm.

Carapace (Fig. 1D): As in previous stage, but with 6-9 setae on posterolateral region; small spines on surface of DS and LS more reduced than in previous stages.

Antennule (Fig. 3C): As in Zoea II, but with 3 aesthetascs and 2 setae.

Antenna (Fig. 4C): As in Zoea II, but with endopod developing.

Mandible: As in Zoea II.

Maxillula (Fig. 6C): As in Zoea II, but with 1 seta on inner margin of basal endite.

Maxilla (Fig. 8C): Endopod bilobed with 2, 2 setae; basal endite bilobed with 5, 5 serrate spines; coxal endite bilobed with 3, 3 serrate spines; scaphognathite with 13 plumose setae.

Maxilliped 1 (Fig. 10C): Basis with 6-7 sparsely plumose setae; exopod with 8 plumose setae, endopod 5-segmented with 2, 2,2,2,5 sparsely plumose setae.

Maxilliped 2 (Fig. 12C): Basis with 4-5 sparsely plumose setae; exopod with 8 plumose setae; endopod 3-segmented with 0, 1,6 sparsely plumose setae.

Maxilliped 3: Buds, larger than in previous stages.

Abdomen (Fig. 14C): As in Zoea II, but with 6 somites, 1 seta on somite 1.

Telson (Fig. 14C): With 4 pairs of setae on posterior margins; 1 spine on dorsal surface of the inner posterior marginal seta. 


\section{Zoea IV}

Size: CL $0.90-1.05 \mathrm{~mm}$; DS-RS 2.73-2.95 mm.

Carapace (Fig. 1F): As in previous stages, but with approximately 17 spines and 15 plumose setae on each posterolateral margin, 1 pair of setae on each side of posterior margin; DS and LS without small spines on surface, LS further reduced.

Antennule (Fig. 3D): As in previous stage, but with 4 aesthetascs, the 2 setae more developed.

Antenna (Fig. 4D): As in Zoea III, but endopod more developed.

Mandible (Fig. 5C): Incisive process with dorsal and ventral terminal teeth well developed.

Maxillula (Fig. 6D): Endopod and protopod as in previous stages; basal endite with 8 serrate spines and 2 plumose setae; coxal endite with 8 serrate spines.

Maxilla (Fig. 8D): Endopod as in previous stage; basal endite bilobed with 7,6 spines; coxal endite bilobed with 3,7 sparsely plumose setae.

Maxilliped 1 (Fig. 10D): Basis with 8 sparsely plumose setae; exopod with 10 plumose setae; endopod with $2,3,2,2,6$ sparsely plumose setae.

Maxilliped 2 (Fig. 12D): Basis with 4-5 setae; exopod with 10 plumose setae; endopod 3-segmented with 0, 1, 5 sparsely plumose setae.

Maxilliped 3: Buds, larger than in previous stages.

Abdomen (Fig. 14D): Somite 1 with 4 sparsely plumose setae.

Telson (Fig. 14D): As in Zoea III, but with 5 pairs of setae on posterior margin.

\section{Zoea V}

Size: CL 1.38-1.42 mm; DS-RS 3.51-3.70 mm.

Carapace (Fig. 2A): With 20 plumose setae on posterolateral margin; DS and LS smooth, LS smaller than in Zoea IV.

Antennule (Fig. 3E): Aesthetascs arranged in 2 tiers. 2-4,5 and 1-2 setae on terminal tier.

Antenna (Fig. 4E): Endopod as long or slightly longer than protopod; exopod more slender than in previous stage.

Mandible (Fig. 5D): Endopod developing near incisive process.

Maxillula (Fig. 6E): Endopod and protopod as in previous stage; basal endite with 14 serrate plus 2 inner setae; coxal endite with 13-15 setose spines.

Maxilla (Fig. 8E): Endopod as in previous stage; basal endite bilobed with 9, 9 serrate spines; coxal endite bilobed with $5,12-14$ setae/spines; scaphognathite with 40 plumose setae.

Maxilliped 1 (Fig. 10E): Basis with 9 sparsely plumose setae; exopod with 12 natatory setae; endopod 5-segmented with 2, 3,2,2,6 setae.

Maxilliped 2 (Fig. 12E): Basis with 4-5 sparsely plumose setae; exopod with 12 plumose setae; endopod 3-segmented with 0,1,7 setae.

Maxilliped 3 (Fig. 13A): Exopod unsegmented; endopod 5-segmented with 1, 1, 1, 3, 6 sparsely plumose setae; epipod naked.

Pereiopods (Fig. 16A): All pereiopods segmented; cheliped developing with 1 spine on subterminal part of dactylus.

Abdomen (Fig. 14E): Segment 1 with a ring of setae on dorsal and lateromedial side; 
segments $2,3,4,5,6$ with postero-lateral process more developed.

Telson (Fig. 14E): Furca covered with groups of short spines; inner margin with a row of short spines; 5 pairs of serrate plumose setae on posterior margin.

\section{Zoea VI (additional stage)}

Size: CL 1.58-1.62 mm; DS-RS 3.94-4.12 mm.

Carapace (Fig. 2B): Twenty one fine setae bordering posterolateral margin; DS longer than $\mathrm{RS}$; lateral spines reduced.

Antennule (Fig. 3F): Aesthetascs arranged in 3 tiers. 5, 3, 2, with 1 seta on 2nd and 3rd.

Antenna (Fig. 4F): Endopod longer than exopod, with little protuberances near the terminal part.

Mandible (Fig. 5E): Incisive and molar processes opened in a wider angle, endopod longer than in Zoea $\mathrm{V}$.

Maxillula (Fig. 6F, G): Endopod 3-segmented with 1, 1, 4 sparsely plumose setae; basal endite with 15 spines/setae; coxal endite with 14-15 spines/setae; protopod with 1 long plumose seta.

Maxilla (Fig. 8F): Endopod bilobed with 2, 2 sparsely plumose setae; basal endite bilobed with 11, 11 spines/şetae; coxal endite bilobed with 4, 15 spines/setae; scaphognathite with 46-48 plumose setae.

Maxilliped 1 (Fig. 10F): As in Zoea V, but exopod with 14 setae and basis with 10-11 setae.

Maxilliped 2 (Fig. 12F): Basis with 4 setae; exopod with 14 terminal plumose setae; endopod 3-segmented with $0,1,7$ sparsely plumose setae.

Maxilliped 3: Exopod without setae, endopod as in Zoea $V_{i}$ epipod with 18-20 setae.

Pereiopods: More developed than in Zoea V; cheliped well developed.

Abdomen (Fig. 14F): First segment with a file of 10 sparsely plumose setae; pleopods more developed than in Zoea $\mathrm{V}$.

Telson (Fig. 14F): Furca with 2 files of short spines on internal margin; 5 pairs of serrate, plumose setae and 1 pair smooth (internal); 1 pair of short seta on dorsal medial part.

\section{Megalopa (regular stage)}

Size: CL 1.37-1.55; CW 1.71-1.82; TL 4.62-4.70.

Carapace (Fig. 2D): Globose on posterior part, narrowing to frontal part; frontal region with a triangular depression; medio-dorsal part often with a vault; rostrum bended downwards, with a deep median wrinkle; anterodorsal and postero-lateral margins with short setae; sometimes a short dorsal posteromedial spine or protuberance.

Antennule (Fig. 3G): Peduncle 2-segmented with 2 setae on proximal and 1 lateral spine on distal segment; exopod 4-segmented with 0, 5, 4,3 aesthetascs arranged in 3 tiers on segments $2,3,4$ respectively; 2 sparsely plumose setae on fourth segment; endopod unsegmented with 2 terminal and 1 subterminal setae.

Antenna (Fig. 4G): Ten-segmented, setation 2, 2, 2, 0, 0, 6, 1, 3, 3, 2-3.

Mandible (Fig. 5F): Symmetrical, semicircular; palp 2-segmented, setation 0, 8-9.

Maxillula (Fig. 7A): Protopod with 2 sparsely plumose setae; endopod 2-segmented, setation 3,3 ; basal endite with 22 spines and 3 naked setae; coxal endite with 27-29 
spines/setae.

Maxilla (Fig. 9A): Endopod bilobed with 2, 2 sparsely plumose setae; basal endite bilobed with 11,11 spines/setae; coxal endite bilobed, with 4 plumose setae, 12 spines/setae; scaphognathite with 70-72 plumose setae.

Maxilliped 1 (Fig 11A): Exopod 2-segmented, setation 1-2, 8-9; endopod unsegmented with 8 lateral, 4 subterminal and 3 terminal setae; basal endite with 14 setae; coxal endite with 19-20 setae; epipod with 11 long setae.

Maxilliped 2 (Fig. 12G): Exopod 2-segmented, setation 0, 9, basal segment with 1 spine; endopod 4-segmented, setation 4, 0,5,13, without epipod.

Maxilliped 3 (Fig. 13B): Exopod 2-segmented, setation 0, 4; endopod 4-segmented, setation $11,6,8,7$; coxa and basis not differentiated, with 16 setae; epipod with $37-40$ setae; protopod covered with sparsely plumose setae of different size.

Pereiopods (Fig. 16B, E, G, I, K): Chelipeds symmetrical with 4-8 irregular teeth on dactyl, covered with short spines/setae irregularly distributed; basis with a file 13-15 sparsely plumose setae; dactyl of $P_{2}$ and $P_{4}$ with 3 ventral spines; $P_{3}$ with 4 ventral spines; dactyl of $P_{5}$ with 3 long terminal setae.

Abdomen (Fig, 14G): Six somites, segments 2, 3, 4 with posterolateral spines well defined; segment 5 narrower than the other, with 3 posterolateral setae on each side.

Pleopods (Fig. 15): Five pairs, exopod setation 22, 20-22, 22, 20, 14; endopods with 3, 3, 3, 3,0 hooked setae. $\mathrm{Pl}_{5}$ 2-segmented with 2, 14 plumose setae, without endopod.

Telson (Fig. 14G): Subquadrate, angles rounded with 4 dorsal, 4 lateral setae on each side and 10-12 setae on posterior margin.

\section{Megalopa (additional stage)}

Size: CL 1.96-2.35 mm; CW 1.77-1.83 mm; TL 4.72-4.77 mm.

Carapace: As in Megalopa I, but without dorsal posteromedial spine of protuberance.

Antennule: As in Megalopa I, but with 1 sparsely plumose seta on 2nd segment of peduncle and without lateral spine; exopod with 1st segment more developed.

Antenna: As in Megalopa I, except setation: 5-6, 2, 0-2, 0, 2, 3, 3, 3, 3, 3.

Mandible: As in previous stage.

Maxillula (Fig. 7B): Protopod with 1 sparsely plumose seta, endopod 2-segmented, setation 3, 4, 2 spines/setae; basal endite with 26 spines/setae; coxal endite with 26-29 spines/setae.

Maxilla: As in Megalopa I, but basal endite bilobed with 13, 12, spines/setae; coxal endite bilobed with 6, 18-22 spines/setae; scaphognathite with 72-76 plumose setae.

Maxilliped 1: As in Megalopa I, but with more lateral setae on endopod, basal endite with 18-20, coxal endite with 19-22, epipod with 15 setae.

Maxilliped 2: Exopod 2-segmented, setation 7-9, 8; endopod 5-segmented, setation 4-5, 5-6, 2, 9-10, 10-13; epipod developing.

Maxilliped 3: As in Megalopa I, but more setose. Exopod 2-segmented, setation 10, 4; endopod 5-segmented, setation $6-8,5-6,4,5,5$; protopod covered with sparsely plumose setae; epipod with 40-46 setae.

Pereiopods (Fig. 16C, F, H, J, L): Cheliped symmetrical, merus with lateral and medial rows of protuberances; carpus with 3 spines and 3 setae; propodus with 13 setae and 1 file of protuberances; dactyl with a row of protuberances, groups of setae and 
irregular teeth on fingers; ischium of $P_{2}$ with lateral margin covered with teeth; $P_{2}-P_{4}$ similar, covered with setae. $P_{5}$ covered with setae, 1 spine on propodus, without terminal setae.

Abdomen: As in Megalopa I, but covered with short setae, somites without posterolateral spines.

Pleopods: Exopods and endopods of pleopods $1-4$ without setae $\mathrm{Pl}_{5}$ vestigial.

Telson: As in regular Megalopa, covered with short setae.

\section{Crab I}

Size: CW 2.27-2.34 mm; CL 2.57-2.60 $\mathrm{mm}$.

Carapace (Fig. 2E): Rectangular, frontal region bilobed; margins with minute spines, all covered with short setae and punctuated.

Antennule (Fig. 3H): Peduncle 2-segmented, setation 3, 4; exopod 4-segmented with 0 , 3-5, 4, 5 aesthetascs, setation $0,0,0,1$; endopod 2-segmented, setation 0,6 .

Antenna (Fig. 4H): As in Megalopa II, but setation 0, 11, 2, 0, 0, 2, 3, 4, 3, 3, 3 .

Mandible: As in Megalopa II, but palp 2-segmented with 4,17 sparsely plumose setae.

Maxillula (Fig. 7C): Protopod with 2 sparsely plumose setae; endopod with 2 spines and 5 sparsely plumose setae; basal endite with $28-29$ spines/setae; coxal endite triangular with 26-28 plumose setae.

Maxilla (Fig. 9B): Endopod bilobed, setation 2, 1; basal endite bilobed, setation 15, 17; coxal endite bilobed, setation $8,25-27$; scaphognathite with 82 plumose setae.

Maxilliped 1 (Fig. 11B): Exopod 2-segmented, setation 0, 7 ; endopod unsegmented with 38 setae; basal endite with 24 sparsely plumose setae; coxal endite covered with sparsely plumose setae; epipod with 18-20 long setae.

Maxilliped 2: Exopod 2-segmented, setation 18,6; endopod 5-segmented, setation 11 , $6-7,3,13-14,16-17$; protopod with 14 setae; epipod with 18 long setae.

Maxilliped 3 (Fig. 13C): Exopod 2-segmented, setation 28,6; 1 spine on first segment; endopod 5-segmented, setation $31-32,13,3,14,14,9$; protopod covered with sparsely plumose setae; epipod with numerous long setae.

Pereiopods: As in Megalopa II.

Abdomen: As in previous stage, but somites narrowing to telson.

Pleopods: Vestigial, transparent.

Telson: Triangular, covered with short setae.

\section{Crab II}

Size: CW 2.85-3.15 mm; CL 3.02-3.10 mm.

Carapace (Fig 2F): As in crab I, but wider, with setae on frontal region.

Antennule: As in crab I, but peduncle setation 3, 4; exopod setation 0, 0, 1, 1; 0, 5, 4, 4 aesthetascs.

Antenna (Fig. 4I): As in crab I, but setation 2, 12, 10, 3, 0, 0, 3, 2, 3, 3, 4, 13.

Mandible: As in previous stage, but palp setation 5, 15-17.

Maxillula (Fig. 7D): Endopod with 1 sparsely plumose seta on basal part and 8 sparsely plumose and 2 serrate setae; basal endite with 27 spines/setae sparsely plumose; coxal endite covered with spines/setae, protopod with 1 sparsely plumose seta. 
Maxilla: As in crab I, but basal endite bilobed with 30,20 sparsely plumose setae, coxal endite bilobed with 8, 26-28 setae; endopod smooth; scaphognathite with 106-108 plumose setae.

Maxilliped 1 (Fig. 11C): As in crab I, but basal endite with 43 sparsely plumose setae on margins, epipod with 46-48 setae.

Maxilliped 2 (Fig. 12H): As in crab I, but exopod bisegmented with 18, 6 setae; endopod 5-segmented with $13-15,8-9,4,13,18-20$ sparsely plumose setae.

Maxilliped 3: As in crab I, but with more setae on first segment of exopod and on all segments of endopod and on epipod.

Pereiopods: As in crab I, but spines more conspicuous.

Abdomen (Fig. 14I): Segments narrower than in crab I.

Telson (Fig. 14I): As in crab I, but with transverse rugosities.

\section{DISCUSSION}

Larval development of the freshwater-dwelling crab Eriocheir sinensis is similar to that in most marine grapsid species, with normally a prezoea, five zoeal stages, and a Megalopa. Tolerance of the larvae toward very low salinities was found to be weak, except in the first zoeal stage and in the Megalopa (Anger, 1991). These two larval stages continually leave and re-enter estuarine habitats, whereas the larvae of intermediate stages (Zoea II-V) develop in coastal marine waters (Panning, 1936b; Hinrichs \& Grell, 1937). Thus, adaptation to freshwater environments is restricted in the mitten crab to its benthic juvenile and adult life-cycle stages. The same life-cycle strategy has been observed also in a number of other grapsid species that are able to live as juveniles or adults in freshwater, for instance Sesarma angustipes, Chasmagnathus granulata, and Cyrtograpsus angulatus (Anger et al., 1990, 1994). Some other freshwater grapsids, in contrast, show far-reaching life-cycle adaptations, including abbreviated larval development (Rabalais \& Gore, 1985; Anger \& Schuh, 1992).

As an interesting feature, the larval development of $E$. sinensis shows a variability in the number of its larval instars, passing sometimes through an additional (stage VI) Zoea; in one individual, an additional Megalopa stage was observed. Like in most other cases of developmental variability (for review see Gore, 1985), the occurrence of extra stages in E. sinensis was related to unfavourable environmental conditions, where rates of survival and developent were low (here low salinity in combination with low temperature; Anger, 1991). Within the family Grapsidae, variability in the number of larval stages was observed also in Cyclograpsus integer (Gore \& Scotto, 1982), Aratus pisonii (Díaz \& Bevilacqua, 1986, 1987), Metasesarma rubripes (Montú et al., 1990), and Chasmagnathus granulata (Anger, unpubl.). This phenomenon, which is common in caridean shrimps, but not in brachyuran crabs (Gore, 1985), might have an adaptive significance in estuarine and other physically unstable environments, where grapsid species are particularly common (Sandifer \& Smith, 1979).

The second Megalopa-stage was, in relation to body size, spinulation, and setation of mouth parts, intermediate between the last larval (i.e. the regular Megalopa) and the first juvenile instar. Its general morphology was more similar to that of the regular Megalopa rather than the first juvenile stage. This rare extra stage was not viable in our laboratory cultures; however, this was possibly a consequence of continually unfavourable rearing 
conditions. Transfer to a more suitable salinity-temperature regime might have allowed successful further development through metamorphosis. Since similar environmental conditions with low salinities and low temperatures are found in estuarine regions during the season of larval development (in spring), such additional larval stages might occur also in the field.

Schnakenbeck (1933) gave a brief and incomplete morphological description of $E$. sinensis larvae, with only a few details of the Zoea $I_{1}$ Megalopa, and juvenile. The following differences may be seen between his and the present description. The dorsal spine of the Zoea I as depicted by Schnakenbeck appears smooth, whereas we observed a spinulation on its surface, persisting through the Zoea III stage. The same applies to the lateral telson spines in this stage, which lack spinulation in Schnakenbeck's description, but did reveal spinules in the Zoea I-IV of our material. Moreover, Schnakenbeck described a somewhat deviating setation for the endopods of zoeal maxillipeds 1 and $2(0$, $1,1,2,5$ and $0,0,6$, respectively; our material, cf. Table 1), and in the antennule he showed no aesthetascs and only 2 setae. The Megalopa described by Schnakenbeck is similar to that in the present paper, but again, appears relatively smooth. In particular, we found the pereiopods covered with more setae and spines. In the first juvenile crab, a merus denticulation was observed which was not described by Schnakenbeck. Although some intraspecific variation certainly occurs, most of these differences may be the result of a less detailed morphological analysis of Schnakenbeck's material.

The present material originates from the German North Sea coast, where $E$. sinensis was introduced about eight decades ago, and where selection conditions differ from those in the species' (mostly subtropical) environments of origin (in China). This isolation might already have allowed the evolution of some differences in larval morphology and, hence, might partly explain differences between the material studied earlier by Schnakenbeck (1933) and that of the present study. This however could only be ascertained by a direct morphological comparison of larvae obtained from a Chinese population with the description given here. In another introduced crustacean species, the barnacle Elminius modestus, Harms (1986) showed that the larvae of a population in the North Sea have different body sizes and responses to temperature as compared with two populations from the region of origin (New Zealand), only four decades after being introduced.

Comparison of larval morphology in E. sinensis and Eriocheir japonicus with that in Eriocheir rectus is difficult, since Shy \& Yu (1992) did not describe in detail the development of all appendages in the latter species. The comparison made in our Table 1 is therefore partly based on drawings rather than on detailed information given in the text or in the morphological tables of Shy \& Yu and hence is in this respect not entirely reliable. According to this incomplete comparison, the zoeal stages may be distinguished most easily by means of morphological differences in the antennules and maxillipeds 1 and 2; the number of aesthetascs and setae is different in all three species compared here (Table 1). A greater overlap seems to occur between the Zoea II of Eriocheir rectus and Eriocheir japonicus, but setation of maxilliped 2 should also allow here a clear separation.

Since Li et al. (1993) concluded from molecular genetic and morphometric data that Eriocheir sinensis and Eriocheir japonicus were only varieties of a single species, the comparison of their larval morphology is particularly interesting. As can be seen in Table 1, there are marked differences in the setation and spinulation of the zoeal carapace (except in the Zoea II), the antennules, and maxilliped 1. In the Megalopa, the 
shape of the rostrum and, again, the morphology of the antennule are different in all three Eriocheir species. The rostrum of the Megalopa shows in E. sinensis a deep median wrinkle, which is less pronounced in E. japonicus, and it may be lacking in Eriocheir rectus. In summary, there appear to be enough morphological differences to distinguish between $E$. sinensis and the other two species. This suggests that $E$. sinensis and $E$. japonicus may be very closely related but most probably separate species.

Acknowledgements. This study was conducted within the framework of a cooperative programme between the Biologische Anstalt Helgoland (BAH) and the Centro de Biologia Marinha (CBM) funded by the GKSS Forschungszentrum Geesthacht, on behalf of the German Federal Ministry of Science and Technology (BMfT, Bonn), and the Comissão Interministerial para os Recursos do Mar (CIRM, Brasilia). We thank J. Willführ-Nast, who helped to remove errors in an earlier version of this paper.

\section{LITERATURE CITED}

Anger, K., 1991. Effects of temperature and salinity on the larval development of the Chinese mitten crab Eriocheir sinensis (Decapoda: Grapsidae). - Mar. Ecol. Prog. Ser. 72, 103-110.

Anger, K. \& Schuh, M., 1992. Bioenergetics of abbreviated larval development in the bromeliad crab, Metopaulias depressus (Decapoda: Grapsidae). - Comp. Biochem. Physiol. 103A, 507-518.

Anger, K., Harms, J., Montú, M. \& de Bakker, C., 1990. Effects of salinity on the larval development of a semiterrestrial tropical crab, Sesarma angustipes (Decapoda: Grapsidae). - Mar. Ecol. Prog. Ser. 62, 89-94.

Anger, K., Spivak, E., Bas, C., Ismael, D. \& Luppi, T., 1994. Hatching rhythms and dispersion of decapod crustacean larvae in a brackish coastal lagoon in Argentina. - Helgoländer Meeresunters. $48,445-466$.

Bianchini, A. \& Gilles, R., 1990. Cyclic AMP as a modulator of $\mathrm{NaCl}$ transport in gills of the euryhaline Chinese crab Eriocheir sinensis. - Mar. Biol. 104, 191-195.

Buhk, F., 1938. Zur Fortpflanzungsbiologie der Wollhandkrabbe. - Wschr. Aquar. u. Terrarienk. 35 , $776-780$.

Chan, T.-Y., Hung, M.-S. \& Yu, H..P., 1995. Identity of Eriocheir recta (Stimpson, 1858) (Decapoda: Brachyura), with description of a new mitten crab from Taiwan. - J. crust. Biol. 15, 301-308

Díaz, H. \& Bevilacqua, M., 1986. Larval development of Aratus pisonii (Milne Edwards) (Brachyura, Grapsidae) from marine and estuarine environments reared under different salinity conditions. J. coast. Res. 2, 43-49.

Díaz, H. \& Bevilacqua, M., 1987. Early developmental sequences of Aratus pisonii (H. Milne Edwards) (Brachyura, Grapsidae) under laboratory conditions. - J. coast. Res. 3, 63-70

Gore, R. H., 1985. Molting and growth in Decapod larvae. In: Larval growth. Ed. by A. M. Wenner. Balkema, Rotterdam, 1-65.

Gore, R. H. \& Scotto, L. E., 1982. Cyclograpsus integer H. Milne Edwards, 1837 (Brachyura, Grapsidae): the complete larval development in the laboratory, with notes on larvae of the genus Cyclograpsus. - Fish. Bull. U.S. 80, 501-521.

Harms, J., 1986. Effects of temperature and salinity on larval development of Elminius modestus (Crustacea, Cirripedia) from Helgoland (North Sea) and New Zealand. - Helgoländer Meeresunters. $40,355-376$.

Hinrichs \& Grell, K.G., 1937. Entwicklungsstadien von Eriocheir sinensis, H. Milne Edwards, im Helgoländer Plankton. - Zool. Anz. 119, 217-221

Kim, C. H. \& Hwang, S. G., 1990. The complete larval development of Eriocheir japonicus De Haan (Crustacea, Brachyura, Grapsidae) reared in the laboratory. - Korean J. Zool. 33, 411-427.

Lee, T.-H. \& Yamazaki, F., 1990. Structure and function of a special tissue in the female genital ducts of the Chinese freshwater crab Eriocheir sinensis. - Biol. Bull. mar. biol. Lab., Woods Hole 178, 94-100.

Li, G., Shen, Q. \& Xu, Z., 1993. Morphometric and biochemical genetic variation of the mitten crab, Eriocheir, in southern China. - Aquaculture 111, 103-115. 
Montú, M., Anger, K. \& de Bakker, C., 1990. Variability in the larval development of Metasesarma rubripes (Decapoda, Grapsidae) reared in the laboratory. - Neritica 5, 113-128.

Panning, A., 1933. Die chinesische Wollhandkrabbe (Eriocheir sinensis H. Milne Edwards) in Deutschland: Gestaltkundlicher Teil - Zool. Anz. (Erg. Bd) 104, 1-58.

Panning, A., 1936a. Die chinesische Wollhandkrabbe in Europa: Der Lebenskreislauf der Wollhandkrabbe. - Fischmarkt 4/5, 4-8.

Panning, A., 1936b. Wandern die Larven der Wollhandkrabbe? - Zool. Anz. 115, 175-177.

Panning, A., 1938. The Chinese mitten crab. - Rep. Smithson. Instn 1938, 361-375.

Panning, A., 1939. Die Larven von Eriocheir sinensis H. M.-Edw. - Zool. Anz. 125, 273-283.

Rabalais, N. N. \& Gore, R. H., 1985. Abbreviated development in Decapods. In: Larval growth. Ed. by A. M. Wenner. Balkema, Rotterdam, 67-126.

Sandifer, P. A. \& Smith, T. I. J, 1979. Possible significance of variation in the larval development of palaemonid shrimp. - J. exp. mar. Biol. Ecol. 39, 55-64.

Schnakenbeck, W., 1933. Die chinesische Wollhandkrabbe (Eriocheir sinensis H. Milne-Edwards) in Deutschland: Larven und erste Bodenformen. - Zool. Anz. (Erg. Bd) 104, 157-170.

Shy, J.-Y. \& Yu, H.-P., 1992. Complete larval development of the mitten crab Eriocheir rectus Stimpson, 1858 (Decapoda, Brachyura, Grapsidae) reared in the laboratory. - Crustaceana 63, $277-290$. 

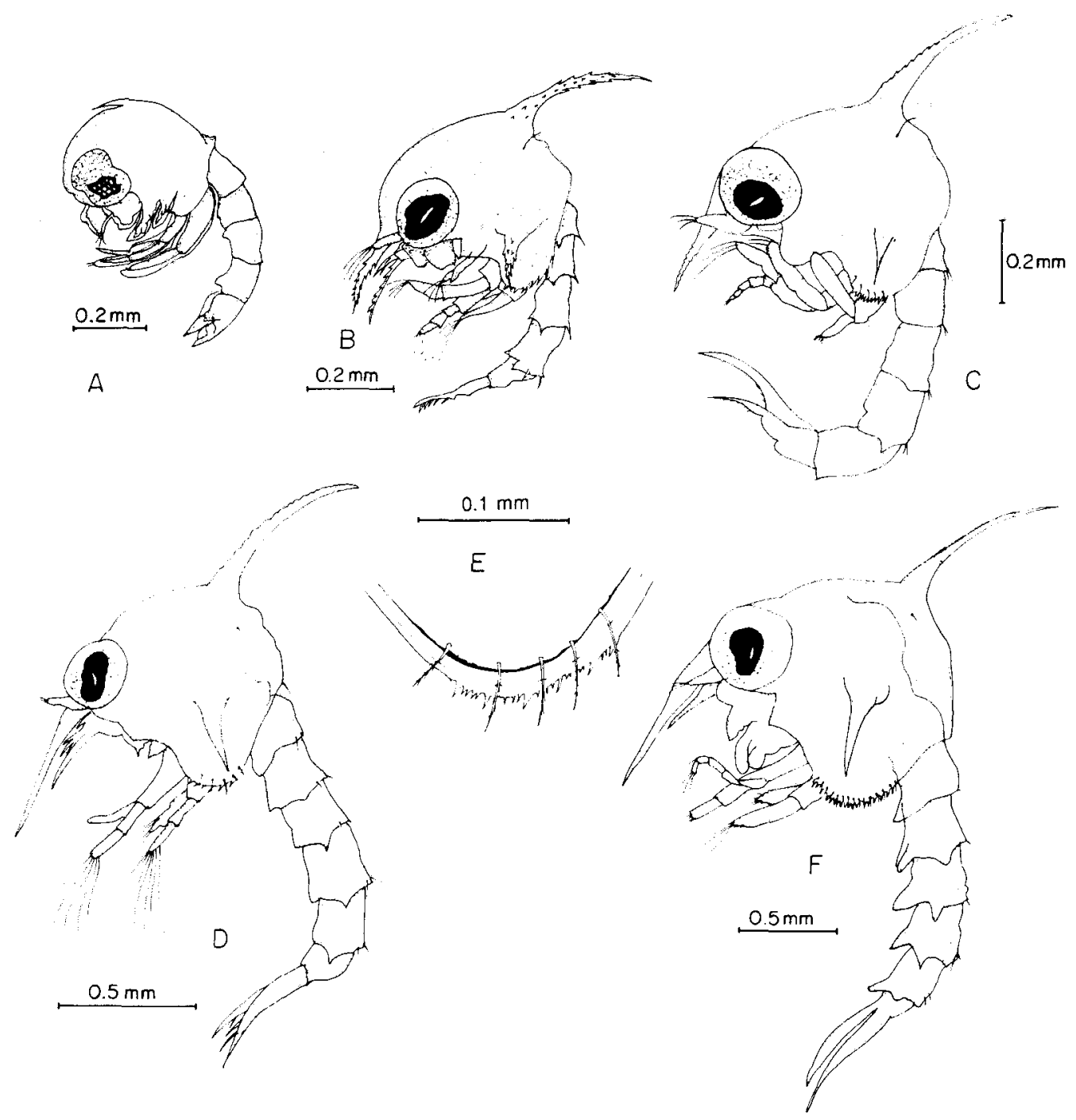

Fig. 1. Eriocheir sinensis. Lateral view of the prezoea and zoea-stages I-IV. A: prezoea; B: Zoea I; C: Zoea II; D: Zoea III; E: detail of carapace (postero-lateral margin) of Zoea III; F: Zoea IV 

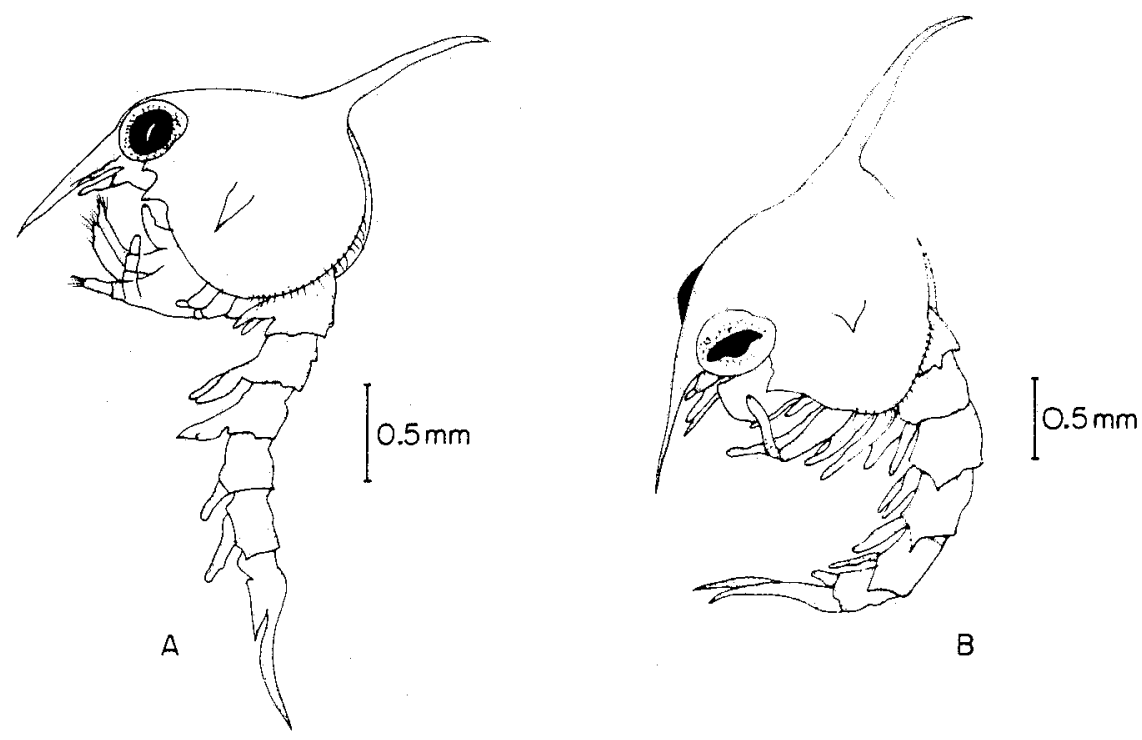

$B$
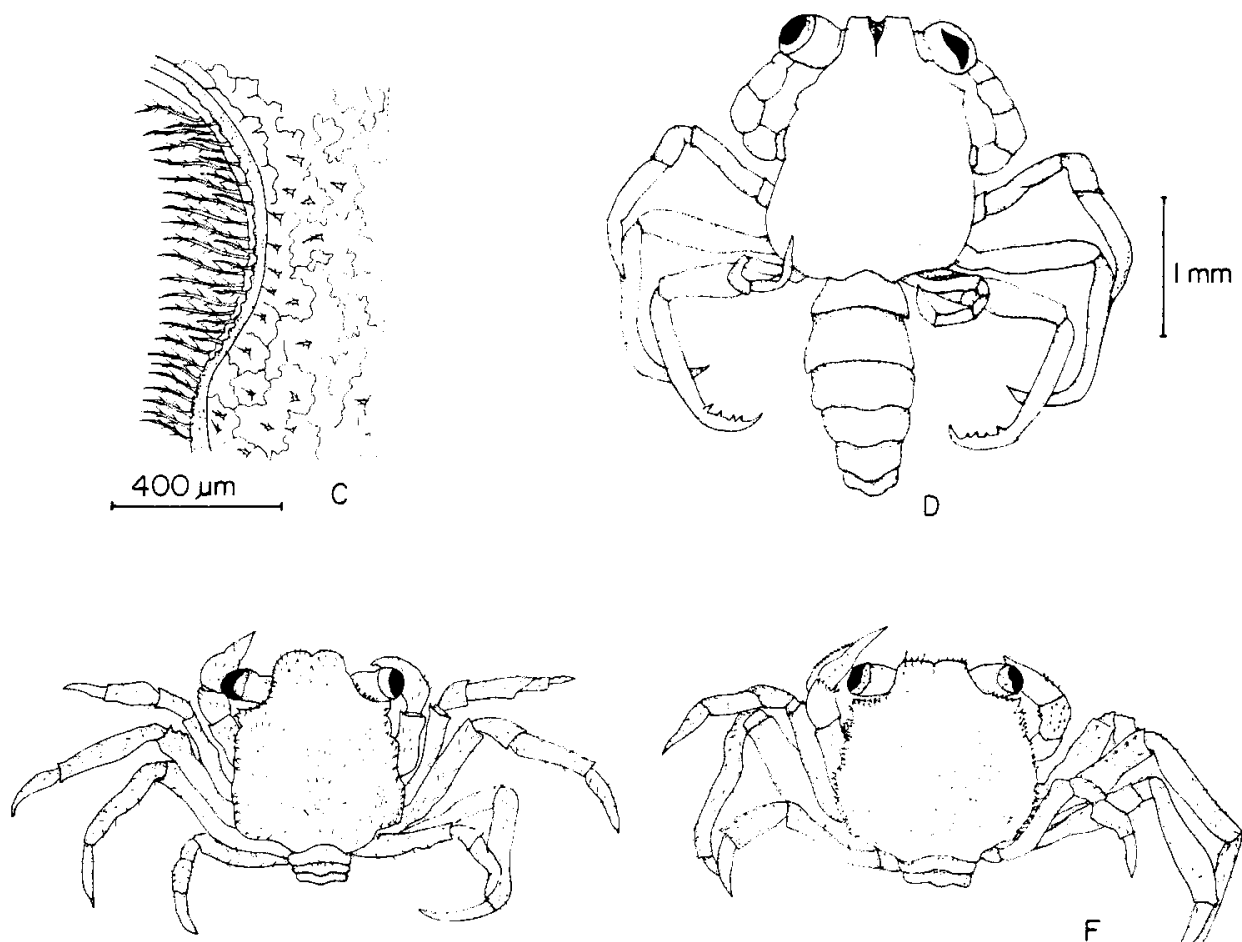

E $3 \mathrm{~mm}$

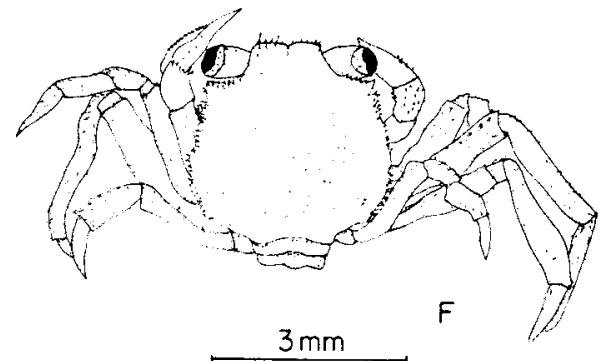

Fig. 2. Eriocheir sinensis. Lateral view of late zoeal stages, dorsal view of Megalopa and early juvenile stages. A: Zoea V; B: Zoea VI (additional stage); C; detail of lateral margin of crab I carapace; D: Megalopa (regular stage); E: crab I; F: crab II 

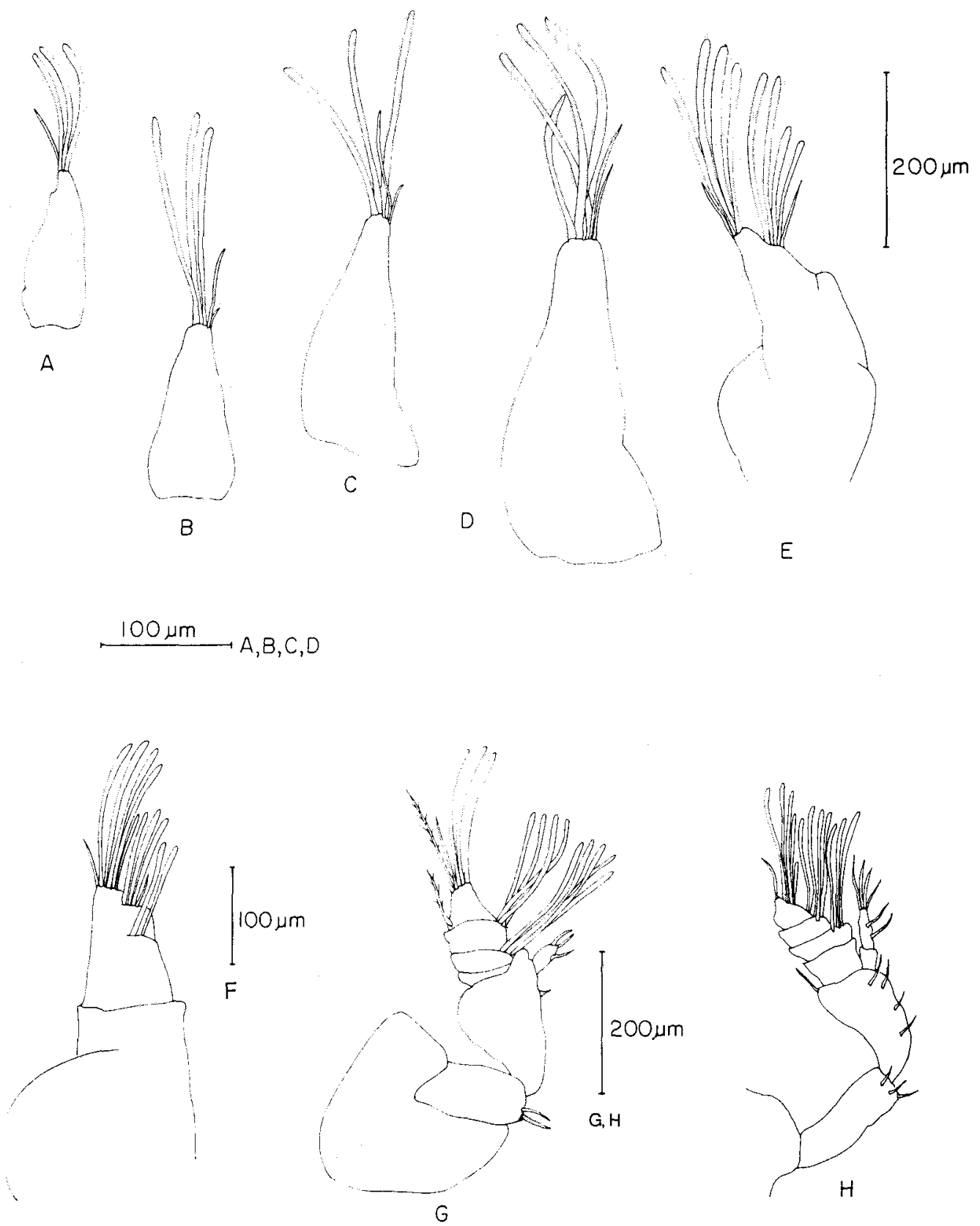

F

Fig. 3. Eriocheir sinensis. Antennule. A: Zoea I; B: Zoea II; C: Zoea III; D: Zoea IV; E: Zoea V; F: Zoea VI (additional stage); G: Megalopa (regular stage); H: crab I 

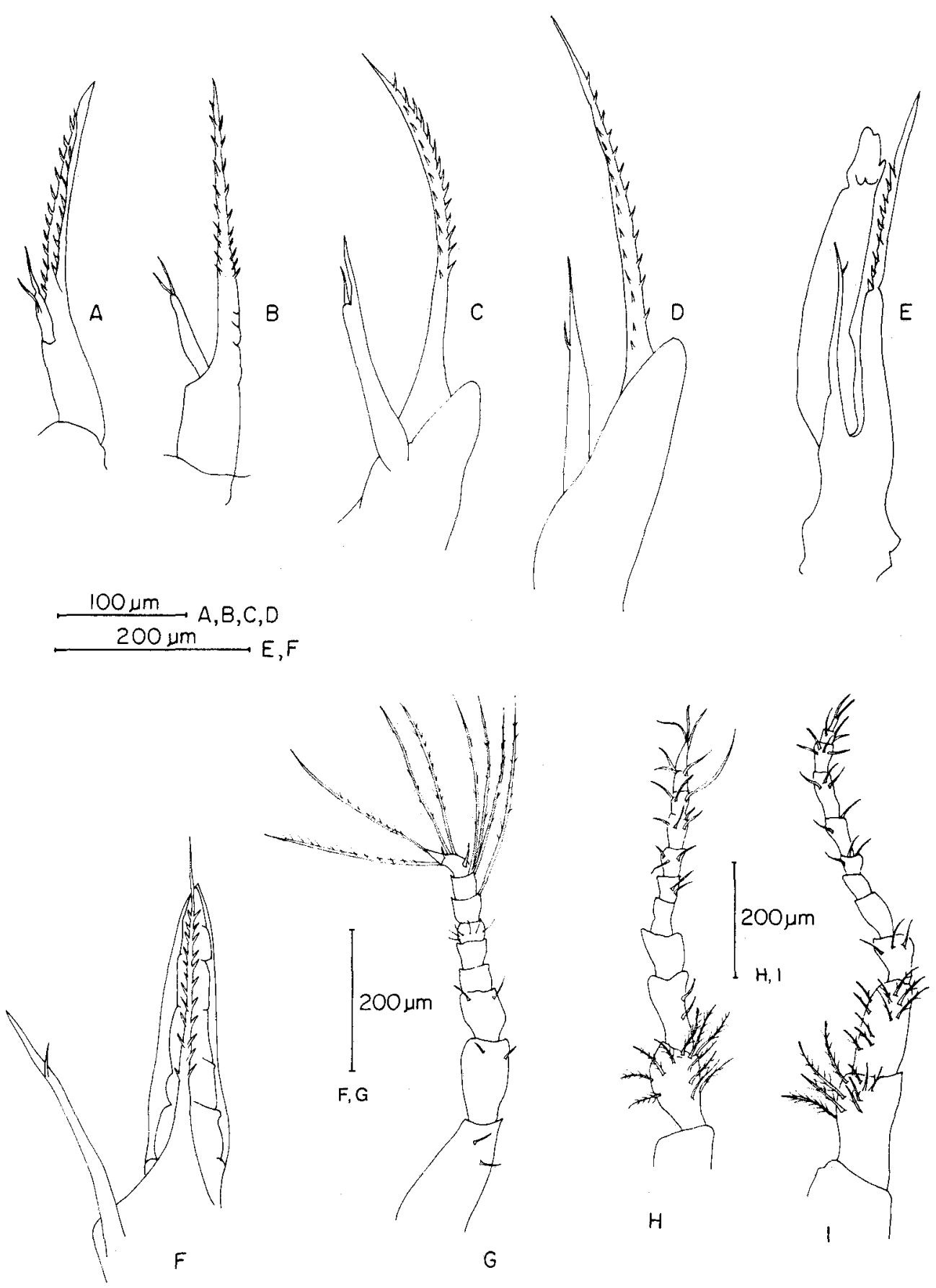

Fig. 4. Eriocheir sinensis. Antenna. A: Zoea I; B: Zoea II; C: Zoea III; D: Zoea IV; E: Zoea V; F: Zoea VI (additional stage); G: Megalopa (regular stage); H: crab I; I: crab II 

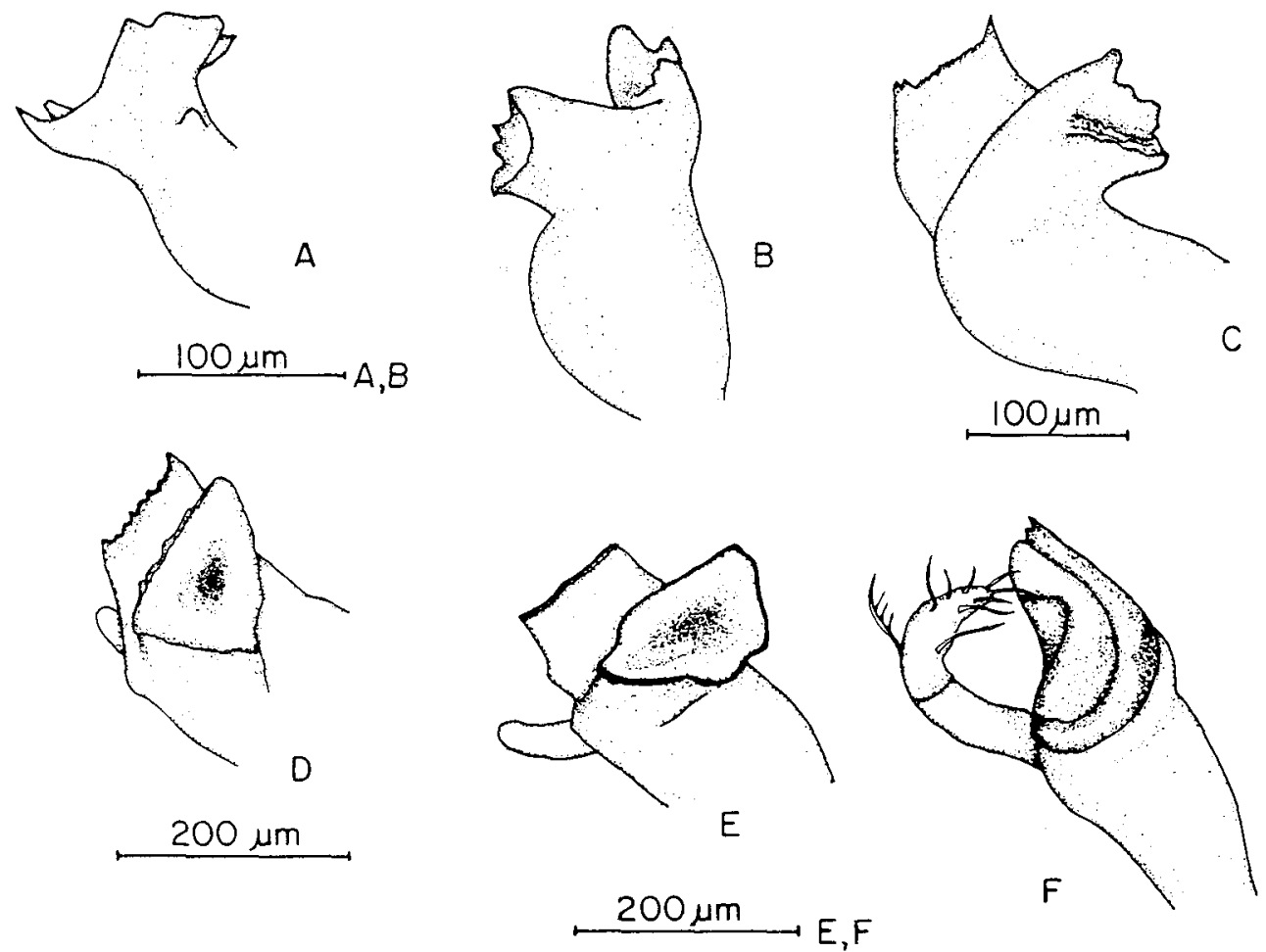

Fig. 5. Eriocheir sinensis. Mandible. A: Zoea I; B: Zoea II and Zoea III; C: Zoea IV; D: Zoea V; E: Zoea VI (additional stage); F: Megalopa (regular stage) 


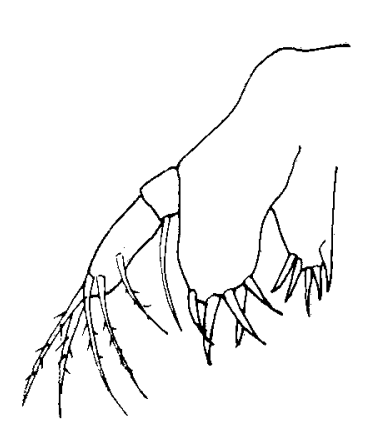

A

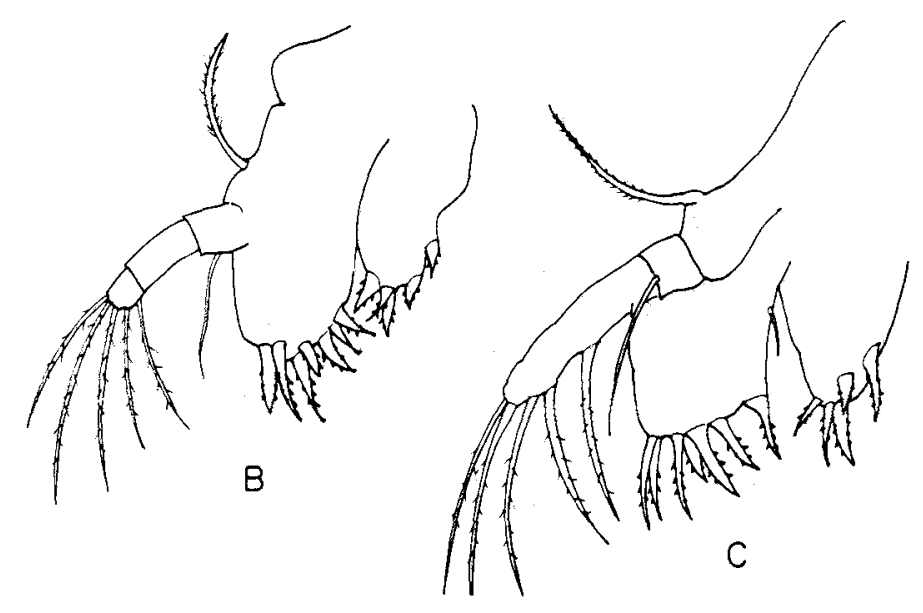

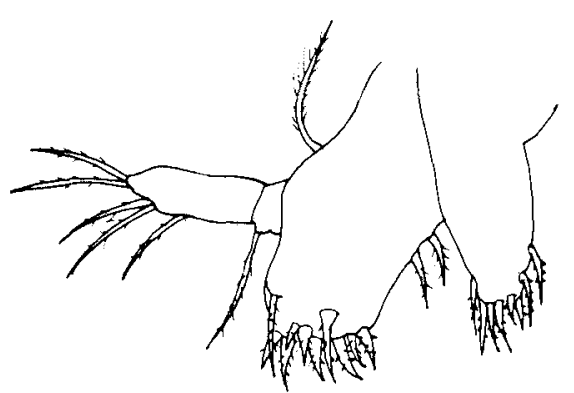

D

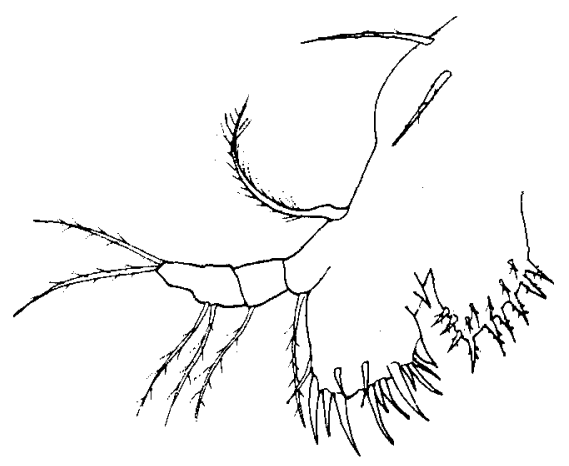

$F$
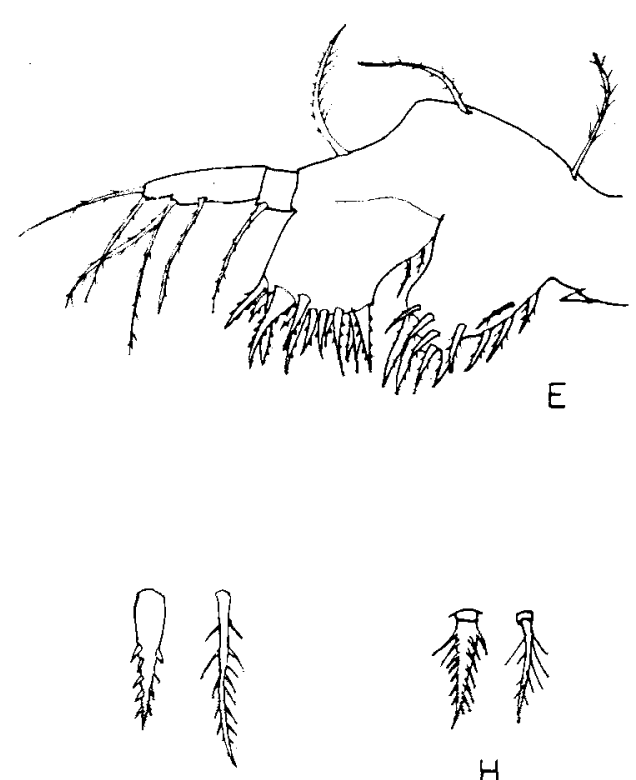

G
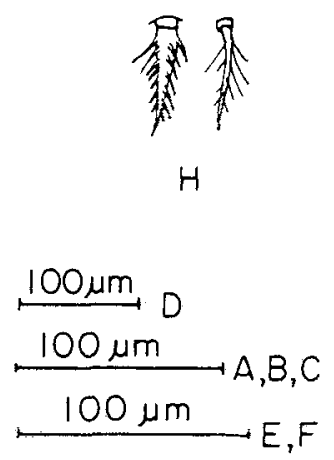

Fig. 6. Eriocheir sinensis. Maxillula of zoeal stages. A: Zoea I; B: Zoea II; C: Zoea III; D: Zoea IV; E: Zoea $V_{i} F$ : Zoea VI; G: detail of setae (cuspidate, multidenticulate) of basal endite of Zoea VI (additional stage); $\mathrm{H}$ : detail of setae of coxal endite of Zoea VI (serrate, sparsely plumose) 

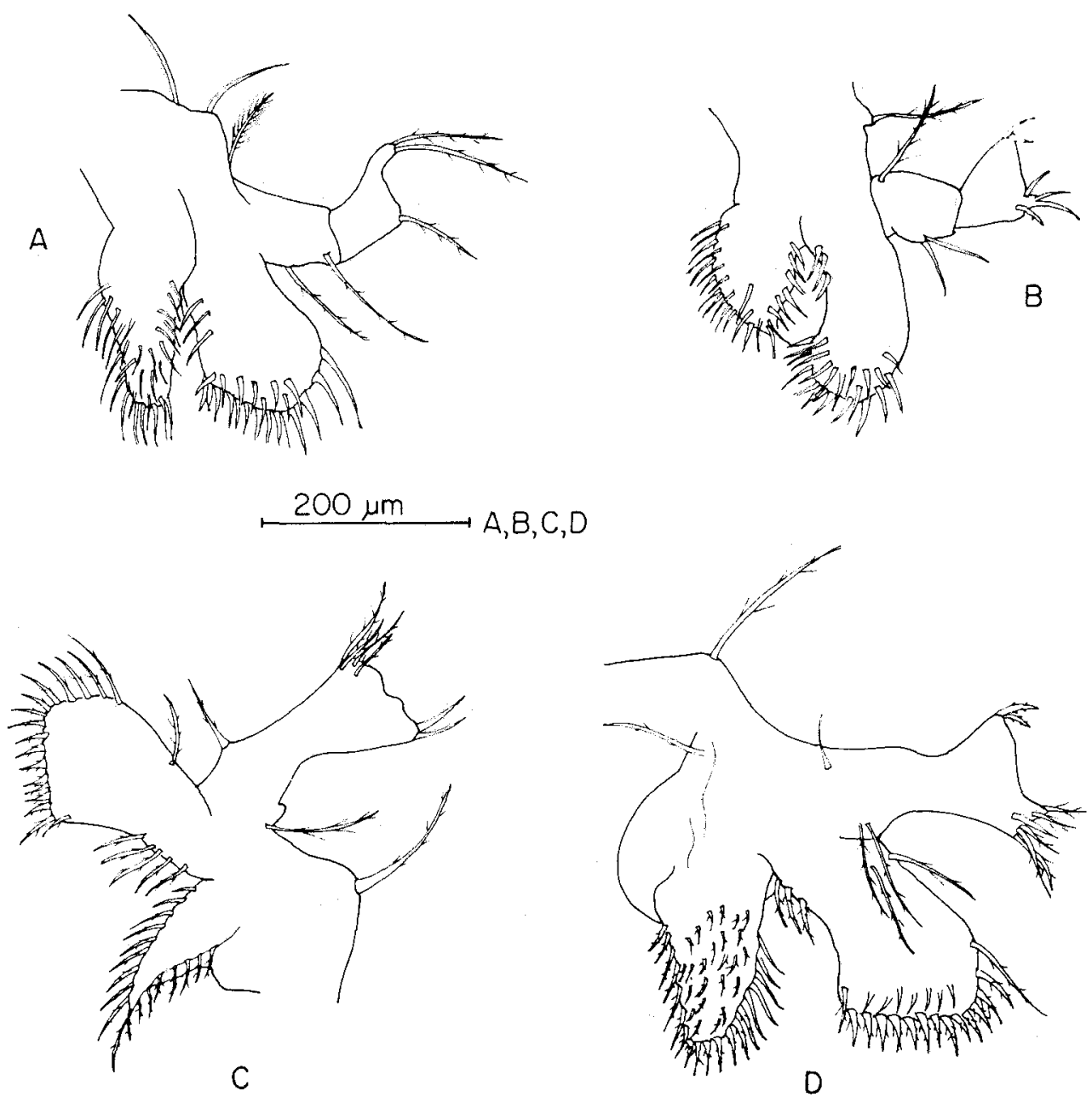

Fig. 7. Eriocheir sinensis. Maxillula of Megalopa and early juvenile stages. A: Megalopa (regular stage); B: Megalopa (additional stage); C: crab I; D: crab II 

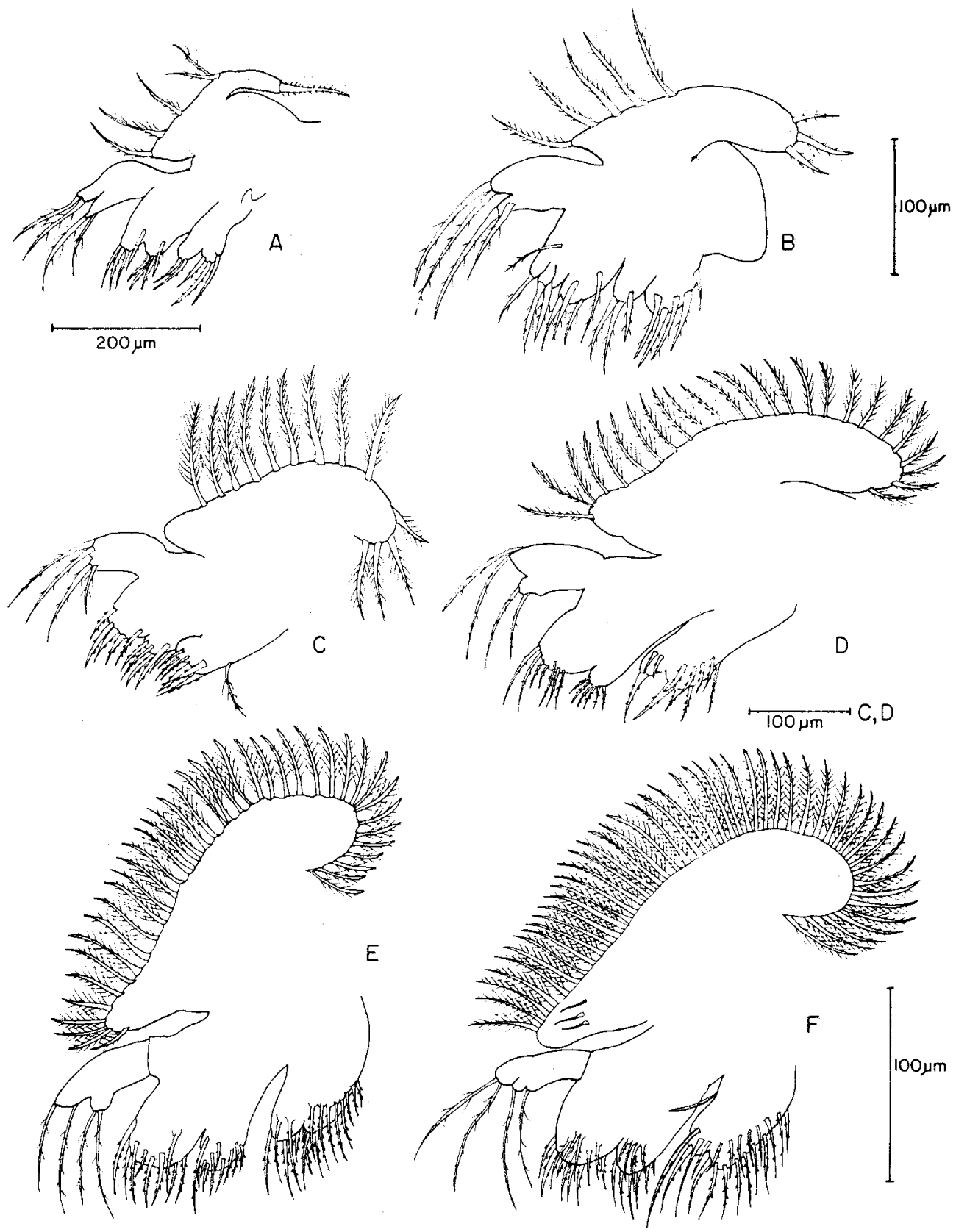

$100 \mu \mathrm{m}$

Fig. 8. Eriocheir sinensis. Maxilla of zoeal stages. A: Zoea Ii B: Zoea II; C: Zoea III; D: Zoea IV; E: Zoea V; F: Zoea VI (additional stage) 

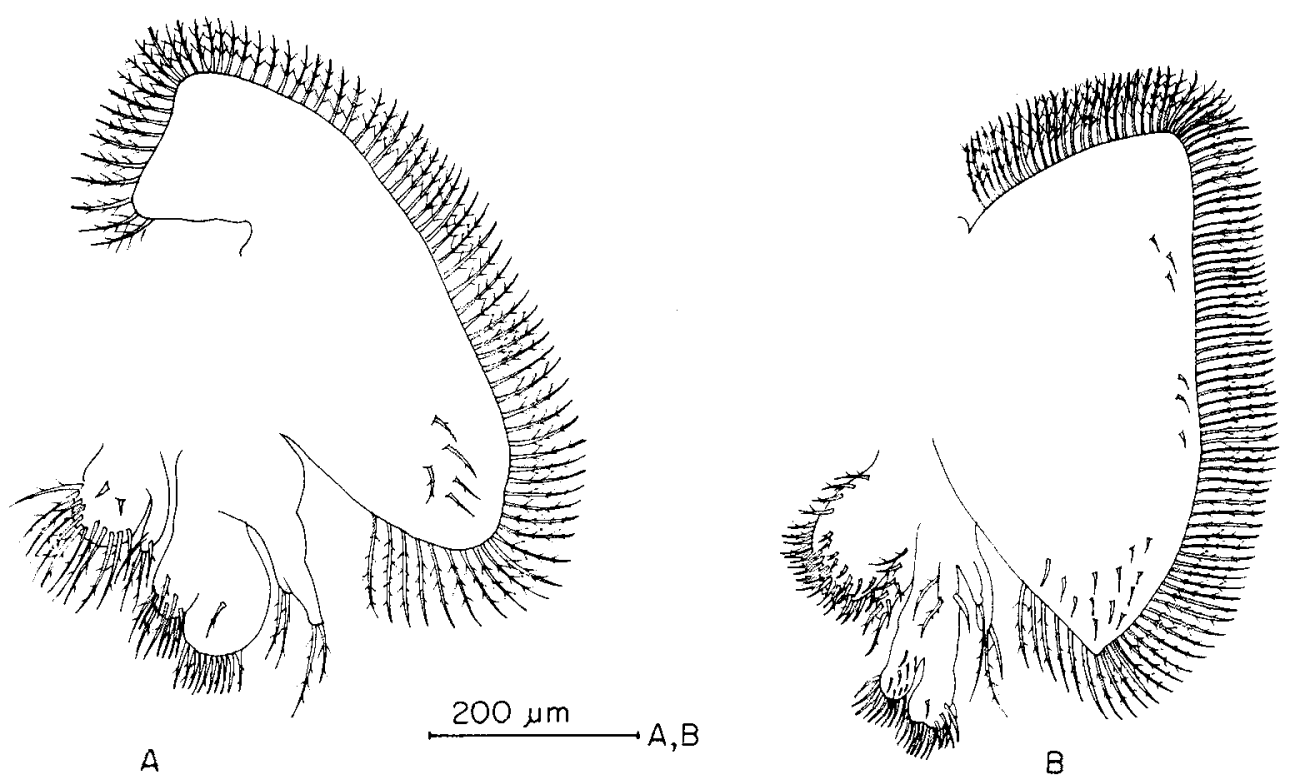

Fig. 9. Eriocheir sinensis. Maxillula of Megalopa and first juvenile stage. A: Megalopa (regular stage); B: crab I 


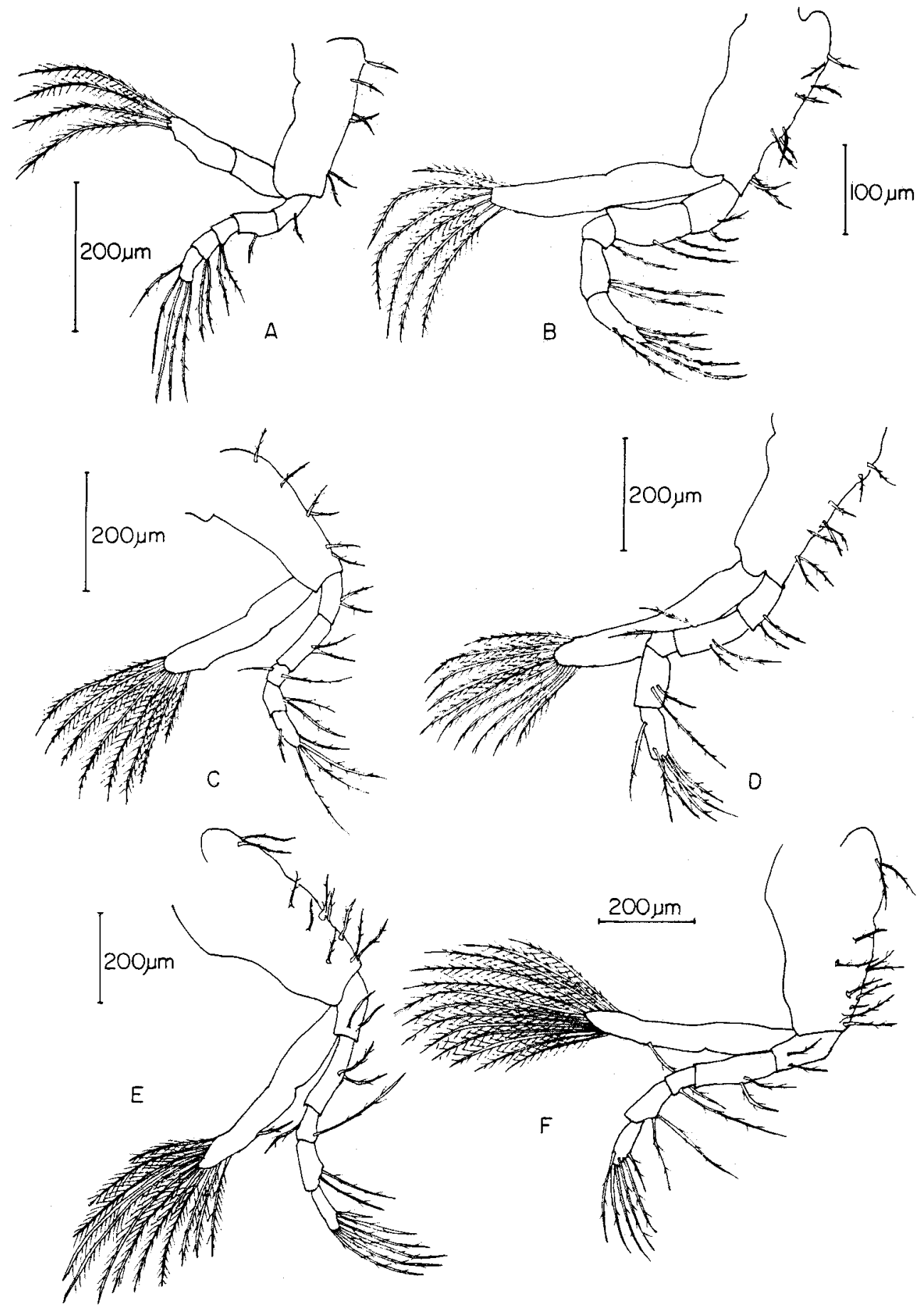

Fig. 10. Eriocheir sinensis. Maxilliped 1 of zoeal stages. A: Zoea I; B: Zoea II; C: Zoea III; D: Zoea IV; E: Zoea V; F: Zoea VI (additional stage) 


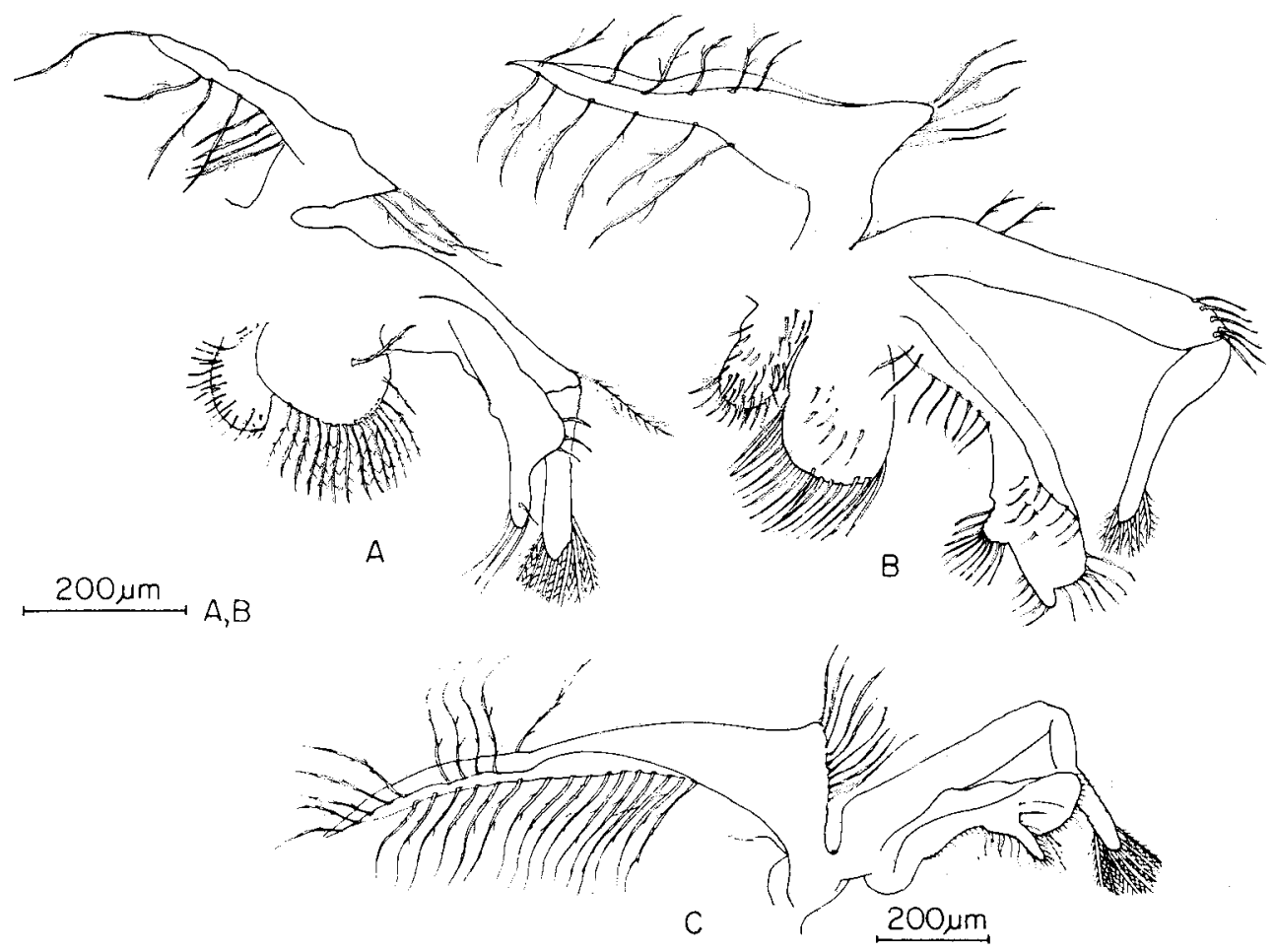

Fig. 11. Eriocheir sinensis. Maxilliped 1 of Megalopa and early juvenile stages. A: Megalopa (regular stage); B: crab I; C: crab II 


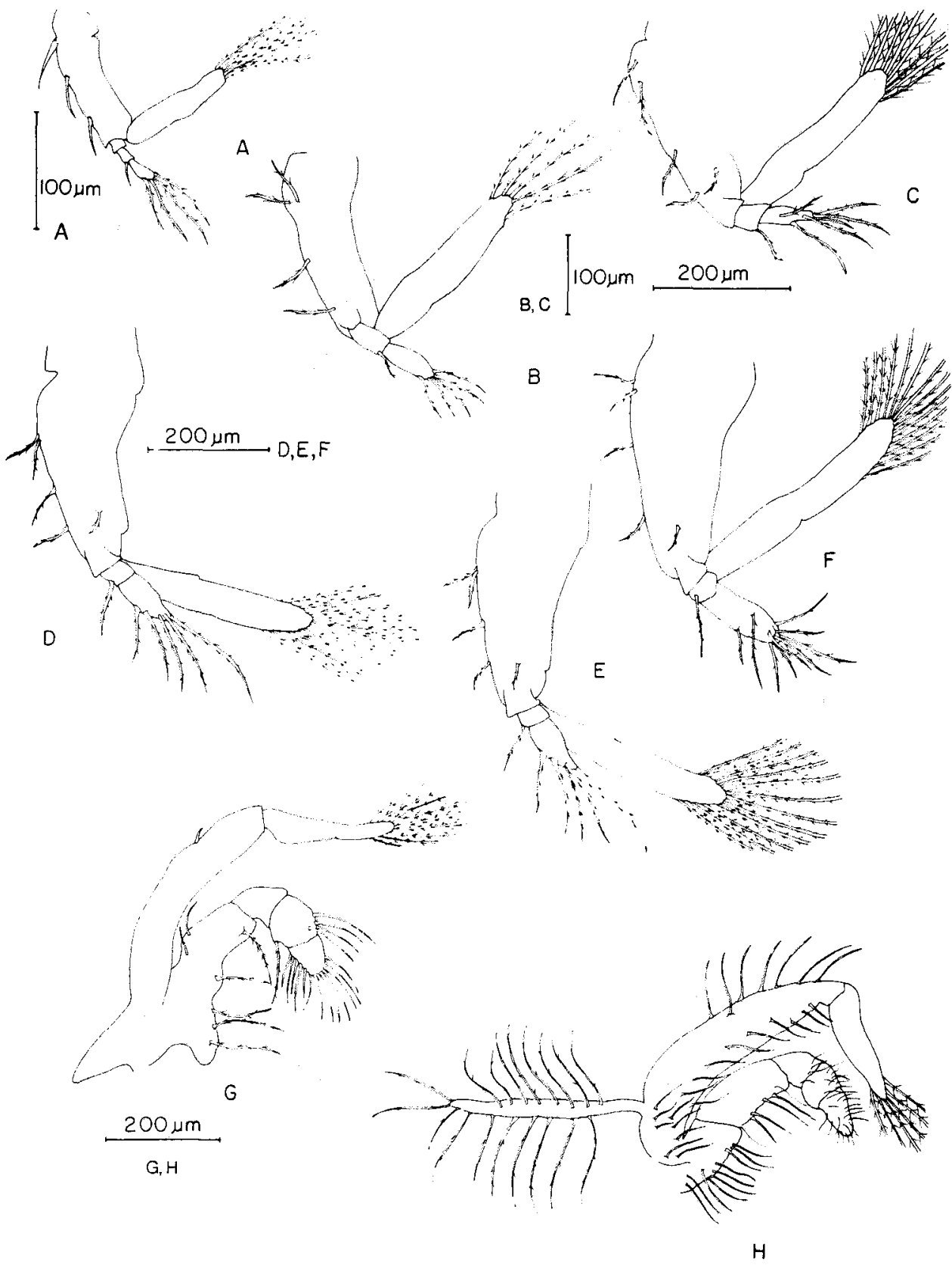

Fig. 12. Eriocheir sinensis. Maxilliped 2. A: Zoea I; B: Zoea II; C: Zoea III; D: Zoea IV; E: Zoea V; F: Zoea VI (additional stage); G: Megalopa (regular stage); H: crab I, II 


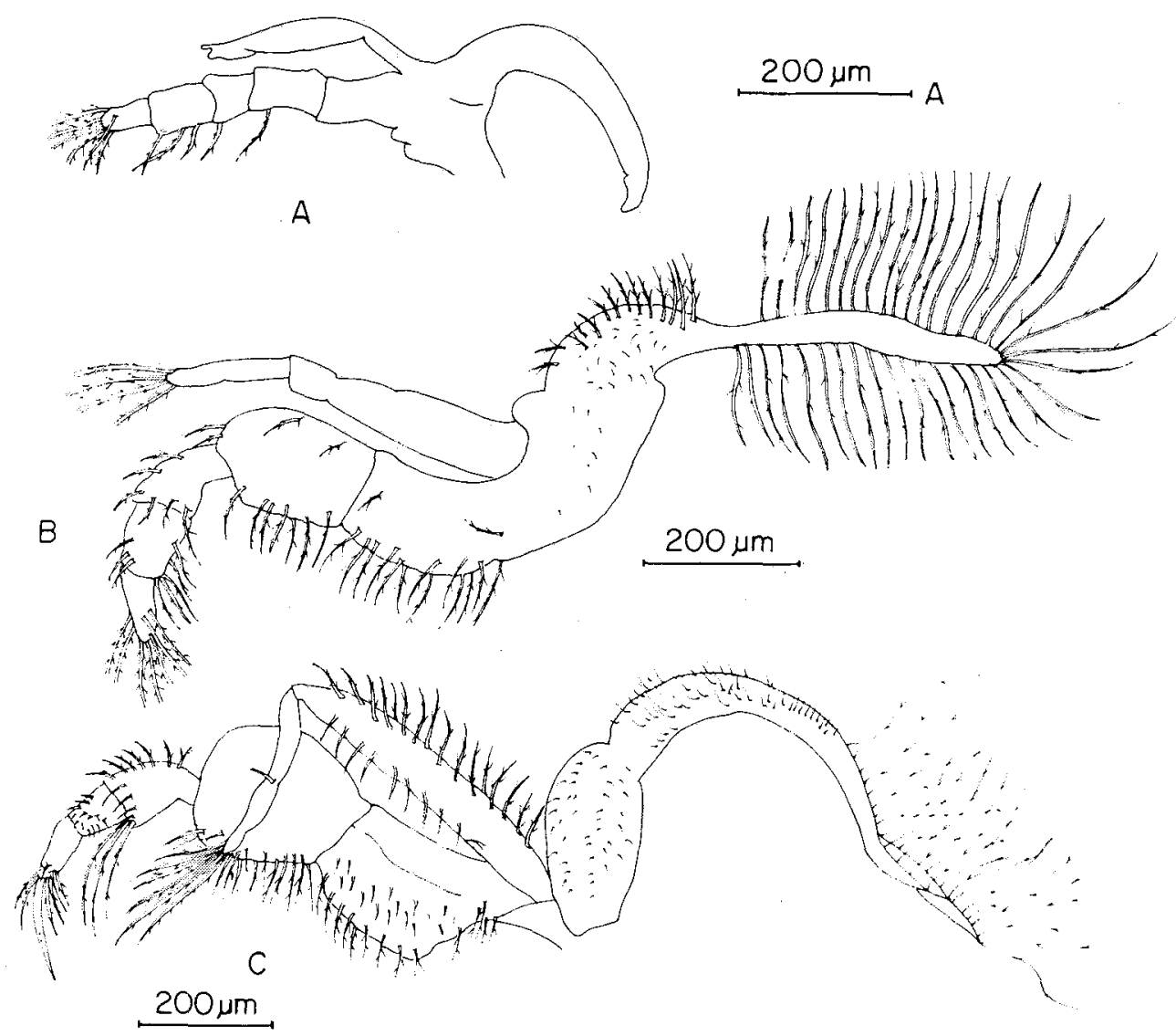

Fig. 13. Eriocheir sinensis. Maxilliped 3. A: Zoea V; B: Megalopa (regular stage); C: crab I 


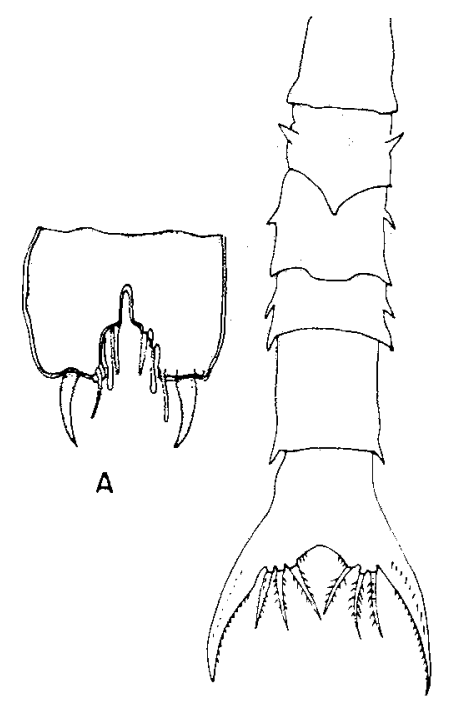

B

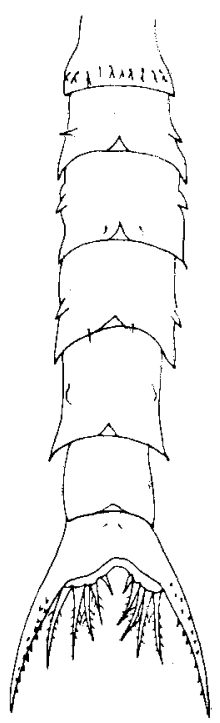

$\mathrm{F}$

G

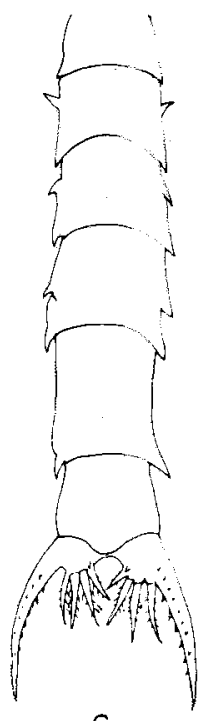

C
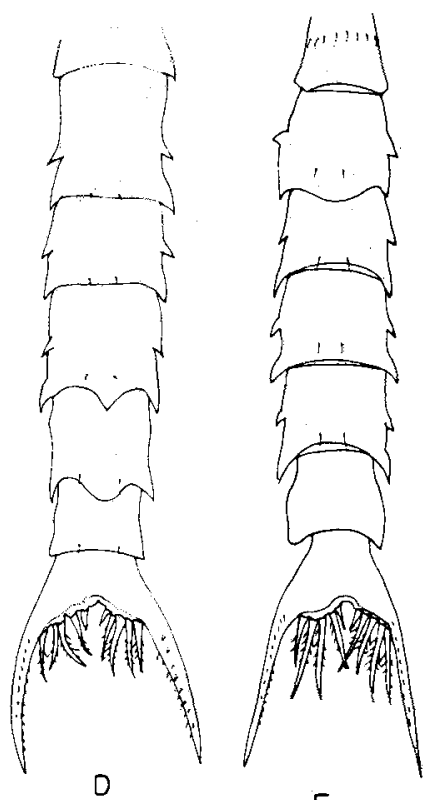

E
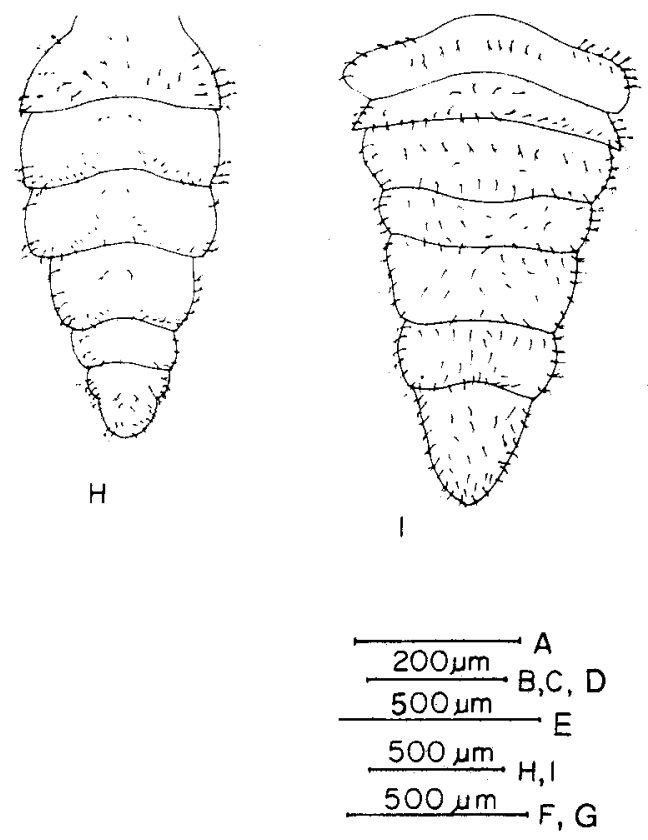

Fig. 14. Eriocheir sinensis. Abdomen and telson, dorsal view. A: telson of prezoea; B: Zoea I and II; C: Zoea III; D: Zoea IV; E: Zoea V; F: Zoea VI (additional stage); G: Megalopa (regular stage); H: crab I; I: crab II 

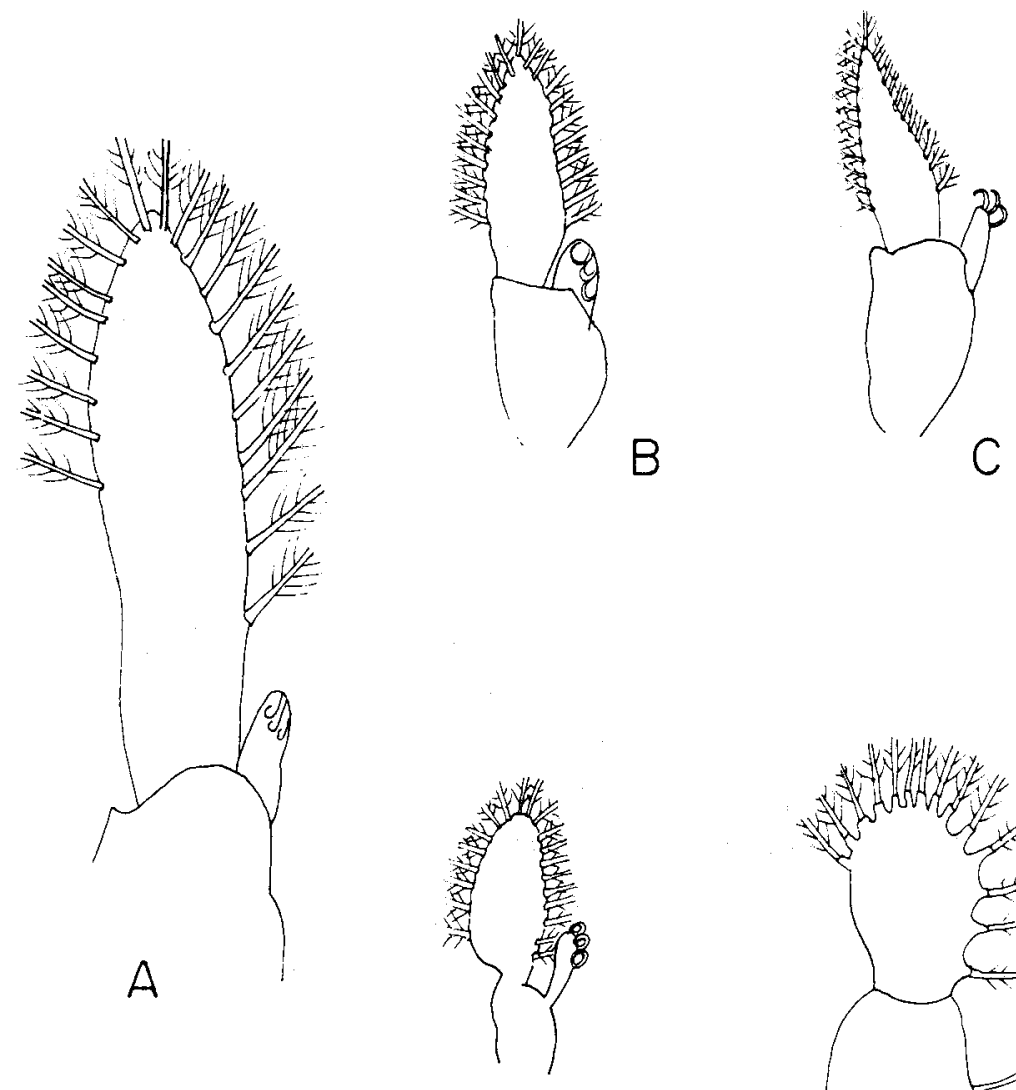

D

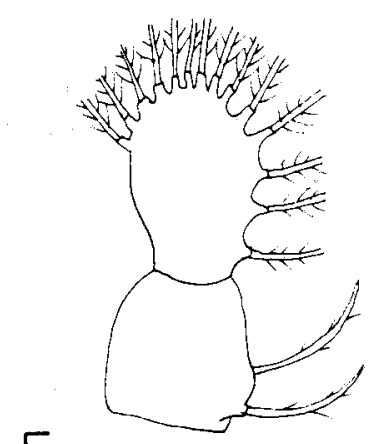

$E$

$200 \mu \mathrm{m}$ A, B,C,D,E

Fig. 15. Eriocheir sinensis. Pleopods (Pl) of Megalopa (regular stage). A: $\mathrm{Pl}_{1 i}$ B: $\mathrm{Pl}_{2 i}$ C: $\mathrm{Pl}_{3 i}$ D: $\mathrm{Pl}_{4}$; $\mathrm{E}: \mathrm{Pl}_{5}$ 


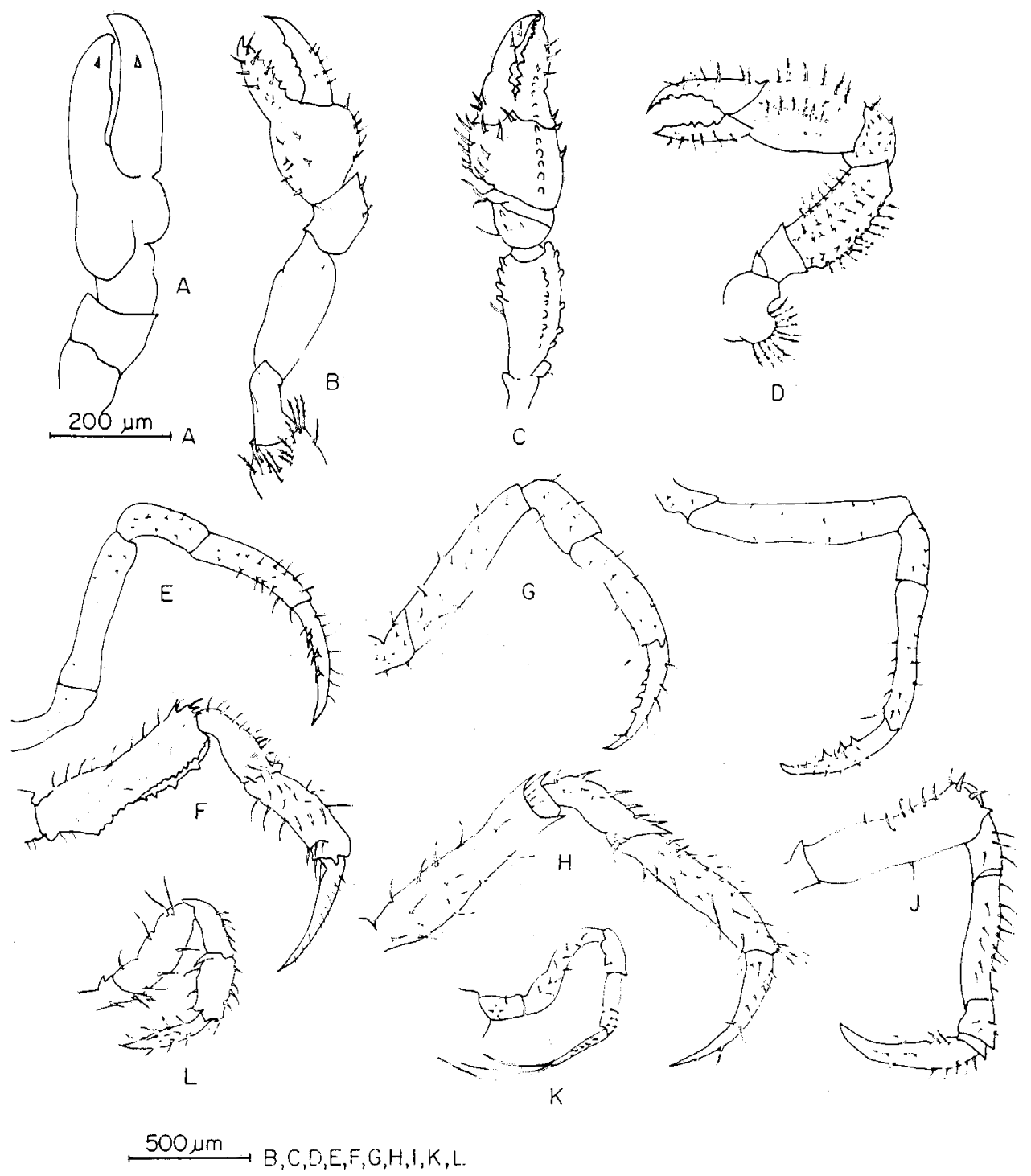

Fig. 16. Eriocheir sinensis. Pereiopods (P). Chelipeds $\left(\mathrm{P}_{1}\right)$. A: Zoea V; B: Megalopa (regular stage, I); C: Megalopa (additional stage, II); D: crab I. $P_{2}$. E: Megalopa I; F: Megalopa II. $P_{3}$. G: Megalopa I; H: Megalopa II. P4. I: Megalopa I; J: Megalopa II. P5. K: Megalopa I; L: Megalopa II 
Table 1. Morphological differences between the larval stages of Eriocheir japonicus (Kim \& Hwang, 1990), E. rectus (Shy \& Yu, 1992; according to Chan et al., 1995, actually E. formosa), and E. sinensis (present study); Megalopa in E. sinensis = regular stage $(\mathrm{I})$. Abbreviations: $\mathrm{a}=$ aesthetascs; dent $=$ denticulate $; \mathrm{pl}=$ plumose $;$ plp $=$ posterolateral projection $;$ plm $=$ posterolateral $\operatorname{margin} ; \mathrm{s}=\operatorname{seta}(\mathrm{e})$; $\mathrm{sc}=$ scaphognathite $; \mathrm{sp}=$ spine $(\mathrm{s}) ; ?$ ? = not clear from original description

\begin{tabular}{|c|c|c|c|}
\hline & Eriocheir japonicus & $\begin{array}{c}\text { E. rectus } \\
\text { (or E. formosa) }\end{array}$ & E. sinensis \\
\hline \multicolumn{4}{|l|}{ Zoea I } \\
\hline Carapace: lateral sp & naked & naked & spinulous \\
\hline s, sp on plm & $10-13,0$ & 0, some $\mathrm{sp}(?)$ & 0,9 \\
\hline Antennule: $\mathrm{a}, \mathrm{s}$ & 2,2 & 2,1 & 3,1 \\
\hline Maxillula: $s$, sp on endopod & 1,4 & $5,0(?)$ & 1,5 \\
\hline Maxilla: $s$, sp on basal endite & 4,5 & $?$ & 4,4 \\
\hline$s, s p$ on coxal endite & 2,4 & $?$ & 2,3 \\
\hline $\mathrm{s}(\mathrm{pl})$, projections on $\mathrm{sc}$ & 4,1 & $?$ & 5,1 \\
\hline Maxilliped 1: $\mathrm{s}$ on basis & 10 & $2(?)$ & 6 \\
\hline s on edopod & $2,2,1,2,5$ & $1,1,1,1,4$ & $1,1,2,2,5$ \\
\hline Maxilliped 2: s on basis & 4 & 0 & 3 \\
\hline s on endopod & $0,1,6$ & 5 (unsegmented) & $0,1,5$ \\
\hline \multicolumn{4}{|l|}{ Zoea II } \\
\hline Carapace: s (pl), sp on plm & $3-4,0$ & 0, some sp (?) & $2-5$, variable \\
\hline Antennule: $a_{,} s$ & 4,1 & 4,1 & 3,2 \\
\hline Maxilla: s, sp on coxal endite & 3,4 & $3,0(?)$ & $3,4-5$ \\
\hline Maxilliped 1: s on basis & 10 & $9(?)$ & $8-9$ \\
\hline Maxilliped 2: $s(\mathrm{pl})$ on exopod & 6 & 6 & 5 \\
\hline s on endopod & $0,1,6$ & 7 (unsegmented) & $0,1,5$ \\
\hline \multicolumn{4}{|l|}{ Zoea III } \\
\hline Carapace: s (pl), sp on plm & $7-9,0$ & 0, some $\mathrm{sp}(?)$ & 5,6 \\
\hline Antennule: $a, s$ & 3,1 & 4,1 & 3,2 \\
\hline Maxillula: s, sp on basal endite & 7 & 8 & 8 \\
\hline$s+s p$ on coxal endite & $6-7$ & 4 & 5 \\
\hline Maxilla: $s+s p$ on basal endite & 11 & 7 & 10 \\
\hline$s+s p$ on coxal endite & 8 & 6 & 6 \\
\hline Maxilliped 1: $\mathrm{s}$ on basis & 10 & $1(?)$ & $6-7$ \\
\hline Maxilliped 2: s on basis & 4 & 0 & 5 \\
\hline \multicolumn{4}{|l|}{ Zoea IV } \\
\hline Carapace: $\mathrm{s}(\mathrm{pl}), \mathrm{sp}$ on plm & $11-14,0$ & 0, some sp (?) & 15,17 \\
\hline Antennule: $\mathrm{a}, \mathrm{s}$ & 4,1 & 5,1 & 4,2 \\
\hline Maxillula: $s+$ sp on basal endite & 13 & 12 & 12 \\
\hline Maxilla: $s+s p$ on basal endite & $15-16$ & 15 & $13-14$ \\
\hline $\mathrm{s}$ on $\mathrm{sC}$ & $24-27$ & 24 & $25-28$ \\
\hline Maxilliped 1: $\mathrm{s}$ on endopod & $2,2,2,2,6$ & $0,2,2,2,4(?)$ & $2,3,1-2,2,2,6$ \\
\hline $\mathrm{s}$ on basis & 10 & 4 & 8 \\
\hline Maxilliped 2: s on endopod & $0,1,6$ & $1,1,5$ & $0,1,5$ \\
\hline$s$ on basis & 4 & 4 & 5 \\
\hline \multicolumn{4}{|l|}{ Zoea V } \\
\hline Carapace: $\mathrm{s}(\mathrm{pl}), \mathrm{sp}$ on $\mathrm{plm}$ & $16-17,0$ & 0, some sp (?) & 20,0 \\
\hline Abdomen: $\mathrm{s}$ (pl) on somite 1 & 7 & $?$ & 9 \\
\hline Antennule: $\mathrm{a}, \mathrm{s}$ & 9,1 & 6,0 & 8,2 \\
\hline Antenna: segments of endopod & 2 & 2 & 1 \\
\hline Maxillula: $s+s p$ on basal endite & 17 & 13 & 16 \\
\hline stsp on coxal endite & 14 & 10 & $13-15$ \\
\hline
\end{tabular}


Table 1 (continued)

\begin{tabular}{|c|c|c|c|}
\hline & Eriocheir japonicus & $\begin{array}{c}\text { E. rectus } \\
\text { (or E. formosa) }\end{array}$ & E. sinensis \\
\hline \multicolumn{4}{|l|}{ Zoea V (continued) } \\
\hline Maxilla: $s+s p$ on basal endite & 20 & 15 & 18 \\
\hline s+sp on coxal endite & 15 & $9(?)$ & $15-19$ \\
\hline $\mathrm{s}$ on sc & $37-41$ & 29 & $48-50$ \\
\hline Maxilliped 1: $s$ on endopod & $2,3,2,2,6$ & $0,2,1,2,4(?)$ & $2,2,2,2,6$ \\
\hline Maxilliped 2: $s$ on basis & 4 & 3 & 5 \\
\hline Telson: s on posterior margin & 5 & 6 & 5 \\
\hline \multicolumn{4}{|l|}{ Megalopa } \\
\hline Antennule: $s$ on endopod & 4 & 3 & 3 \\
\hline$a, s$ & 14,3 & 10,3 & 12,4 \\
\hline Antenna: s on flagellum & $\begin{array}{l}3,2,3,0,0,4,2,4 \\
3,3\end{array}$ & $0,1,2,0,0,1,1,6$ & $2,2,2,0,0,6,1,3,3,2$ \\
\hline Maxillula: s, sp on endopod & 4 & ? & 5 \\
\hline s+sp on basal endite & $27-29$ & $?$ & $24-25$ \\
\hline s+sp on coxal endite & $22-24$ & ? & $27-29$ \\
\hline Maxilla: s on endopod & 5 & 0 & 4 \\
\hline $\mathrm{s}+\mathrm{sp}$ on basal endite & $25-30$ & 8 & $20-22$ \\
\hline s+sp on coxal endite & $26-26$ & 13 & $17-19$ \\
\hline $\mathrm{s}(\mathrm{pl})$ on $\mathrm{sc}$ & $65-72$ & 56 & $70-72$ \\
\hline \multicolumn{4}{|l|}{ Maxilliped 1: } \\
\hline $\mathrm{s}$, sp on exopod & 2,4 & $?$ & $1-2,8$ \\
\hline $\mathrm{s}+\mathrm{sp}$ on basal, coxal endite & $22-25,16-17$ & ? & $14-16,19-20$ \\
\hline Maxilliped 2: $\mathbf{s}$ on basis & $3-5$ & $?$ & 7 \\
\hline s on exopod & 1,5 & $?$ & 1,9 \\
\hline$s$ on endopod & $1,2,7-8,10-11$ & $?$ & $1,0,5,13$ \\
\hline Maxilliped 3: $\mathrm{s}$ on basis & $25-27$ & $?$ & $22-24$ \\
\hline $\mathrm{s}$ on exopod & 7,5 & 0,4 & 0,4 \\
\hline s on endopod & $\begin{array}{l}18-20,14,9-10 \\
17-19,10-11\end{array}$ & $?$ & $15,11,6,8,7$ \\
\hline s on epipod & $28-30$ & $?$ & $37-40$ \\
\hline Abdomen: plp on 5th somite & short & short (?) & long \\
\hline s on plm of 6 th somite & 0 & $?$ & 6 \\
\hline Telson: $\mathrm{s}$ on posterior margin & 3 & $?$ & 10 \\
\hline $\mathrm{s}$ on lateral margin & 0 & $?$ & 4 on each side \\
\hline dorsals $s$ & 0 & $?$ & 4 \\
\hline
\end{tabular}

